\title{
DIREITO AO ESQUECIMENTO E DIREITO À DESINDEXAÇÃO: UMA PRETENSÃO VÁLIDA? COMENTÁRIOS AO ACÓRDÃO PROFERIDO PELO STJ NO RESP № $1.660 .168-$ RJ
}

\author{
RIGHT TO BE FORGOTTEN AND RIGHT TO DE-INDEXATION: A LAWFUL CLAIM? \\ COMMENTS ON THE JUDGMENT BY THE STJ IN RESP No 1.660 .168 - RJ
}

Aprovado: 16.03.2019

\author{
Marcos Ehrhardt Jr. \\ Doutor pela UFPE. Professor de Direito Civil da \\ UFAL e do Centro Universitário CESMAC. \\ E-MAIL: contato@marcosehrhardt.com.br. \\ LATTES: http://lattes.cnpq.br/7254531183116373 \\ ORCID: https:/ / orcid.org/0000-0003-1371-5921.
}

\author{
Jéssica Andrade Modesto \\ Mestranda em Direito Público pela UFAL. \\ Advogada. Servidora Pública Federal. \\ E-MAIL: jessicaandrademodesto@hotmail.com \\ LATTES: http://lattes.cnpq.br/9787795133733646 \\ ORCID: https:/ / orcid.org/0000-0002-2626-5088.
}

\begin{abstract}
RESUMO: A disseminação de informações a respeito de determinada pessoa pode acarretar graves danos à sua privacidade, ainda que estas informações sejam verdadeiras. Diante disso, o trabalho se propôs a investigar se o direito ao esquecimento e o direito à desindexação são reconhecidos no direito brasileiro. Para tanto, realizou-se uma pesquisa bibliográfica/documental acerca do tema em doutrina, legislação e jurisprudência pátrias, bem como analisou-se o acórdão proferido pelo Superior Tribunal de Justiça no julgamento do REsp n ${ }^{0} 1.660 .168$ - RJ. Concluiu-se que, na decisão analisada, a pretensão autoral encontrou respaldo em nosso ordenamento jurídico, no entanto, na prática, seu direito ao esquecimento não foi efetivado.
\end{abstract}

PALAVRAS-CHAVE: Direito ao esquecimento. Direito à desindexação. Direito à privacidade. Responsabilidade civil. Provedores de busca.

\begin{abstract}
The dissemination of information about a particular person can cause serious damage to your privacy, even if that information is true. Whereupon, the study aimed to investigate whether the right to forgetting and the right to deindexation are recognized in Brazilian law. To this, a bibliographic/documentary research was conducted on the subject in doctrine, legislation and jurisprudence, also if analyzed the judgment by the Superior Court of Justice in the judgment of the REsp $n^{\circ} .1 .660 .168$ - RJ. It was concluded that, in the decision analyzed, the plaintiff's claim found support in our legal system, however, in practice, her right to forget was not realized.
\end{abstract}

KEYWORDS: Right to be Forgotten. Right to De-Indexation. Right to Privacy. Civil responsability. Search providers.

SUMÁRIO: 1 Introdução 2 Para compreender o caso: resumo das perspectivas de cada julgador 3 Direito ao Esquecimento e Direito à Desindexação: análise da pretensão da autora no REsp 1660168/RJ 4 O Reconhecimento Constitucional e Infraconstitucional do Direito à Desindexação no Ordenamento Jurídico Brasileiro 5 Conclusão 6 Referências.

78 | Revista do Programa de Pós-Graduação em Direito da UFBA, e-issn 2358-4777, v. 30, n. 01, p.78 -105, Jan-Jun 2020 


\section{Introdução}

O amplo acesso a informações sobre tudo e todos é, hoje, uma realidade que provoca diversas mudanças sociais. Em segundos, podemos encontrar os artigos científicos mais recentes para a pesquisa acadêmica que estamos realizando, nos informar sobre os tratamentos mais inovadores para uma enfermidade que nos acomete, saber qual trajeto devemos tomar para chegar sem atraso ao trabalho, por exemplo.

Nas relações sociais, as visitas corriqueiras aos perfis do outro nas redes de relacionamento nos possibilita satisfazer os sentimentos de curiosidade. Isso sem falar nos sites de busca, nos quais é possível pesquisar o nome de alguém e, dessa forma, ter acesso a diversos dados referentes ao indivíduo pesquisado, os quais constam nas páginas da web e são indexadas pelo buscador, podendo ser bastante reveladores.

São muitas as benesses propiciadas pelos avanços tecnológicos, no entanto, são igualmente vários os problemas que podem surgir nesse cenário. A disseminação de informações a respeito de determinada pessoa, por exemplo, pode acarretar sérios danos à privacidade desse indivíduo mesmo que tais informações sejam verdadeiras.

Assim, não é difícil imaginar a gravidade das consequências sofridas por alguém cujo nome, sempre que é utilizado como parâmetro de busca em algum provedor de pesquisa, retorna dentre os primeiros resultados indexados, uma foto íntima exposta na internet ou uma notícia acerca da prática de uma conduta desabonadora.

Nesse cenário, muitas informações divulgadas sobre alguém estão desatualizadas ou não apresentam qualquer aspecto relevante ao interesse público, de outro lado, contudo, causam graves danos à pessoa cuja informação dizem respeito. Nesses casos, a pessoa lesionada poderia pleitear um "direito ao esquecimento" ou a internet é uma grande memória coletiva que deve conservar, eternamente, qualquer registro nela publicado?

Nesse contexto, questiona-se: existe um direito ao esquecimento? É possível a solicitação da remoção ou da desindexação de determinado dado pessoal exposto na web? Tais pretensões encontram respaldo no ordenamento jurídico brasileiro? Em que condições?

O presente trabalho visa a buscar respostas a tais questionamentos, partindo-se da hipótese que o direito à informação não pode legitimar que dados irrelevantes e desatualizados sejam mantidos na internet em detrimento aos direitos da personalidade do indivíduo a quem essas informações se referem.

Dessa forma, propõe-se investigar como o direito ao esquecimento e o direito à desindexação são vistos, atualmente, pela doutrina, legislação e jurisprudência pátrias, para, assim, delinear seus conceitos. Além disso, o artigo busca analisar se existe reconhecimento de tais direitos nos planos constitucional e infraconstitucional brasileiros, bem como quais são os parâmetros apontados pela doutrina e pela jurisprudência para o acolhimento de demandas acerca do direito ao esquecimento e, em especial, de pleitos que versem sobre o direito à desindexação.

Para tanto, será realizada uma pesquisa bibliográfica/documental acerca do tema na doutrina, jurisprudência e legislação pátrias. Ademais, será feita uma análise detida do acórdão proferido no julgamento do REsp no 1.660.168 - RJ, pelo Superior Tribunal de Justiça, em litígio que versava sobre a obrigação de provedores de busca de evitar a associação do nome da autora a notícias sobre a sua participação em suposta fraude, tendo em vista que, além de ser o julgado mais recente sobre a matéria, a decisão discutiu os precedentes anteriores sobre o assunto, 0 que permite uma compreensão maior do entendimento do Tribunal no que diz respeito ao direito à desindexação. 


\section{Para compreender o caso: resumo das perspectivas de cada julgador}

A análise diz respeito aos recursos especiais interpostos por Google Brasil Internet Ltda., Yahoo! do Brasil Internet Ltda. e Microsoft Informática Ltda. contra acórdão do Tribunal de Justiça do Estado do Rio de Janeiro proferido no Recurso Especial no 1.660 .168 - RJ. ${ }^{1}$

No ano de 2006, a autora participou de um concurso para a magistratura no Rio de Janeiro, contudo, muito embora tenha reprovado na fase oral, houve denúncias de suposta fraude no certame envolvendo seu nome, o que foi publicado em vários sites de notícias. $\mathrm{O}$ caso foi investigado e, ao final, o CNJ considerou hígido o concurso, uma vez que as acusações não foram comprovadas.

Passados mais de dois anos, a autora verificou que, ao realizar uma pesquisa, nos buscadores já citados, utilizando seu nome completo como único parâmetro de pesquisa, estas aplicações retornavam, como primeiros resultados, as notícias referentes às denúncias de fraude.

Diante disso, em agosto de 2009, ajuizou ação de obrigação de fazer em face dos provedores de busca com o objetivo de obrigá-los a se absterem de apresentar, em seus resultados, notícias relacionadas à suposta fraude quando fossem realizadas pesquisas por meio de seu nome.

O juiz de primeiro grau julgou improcedente o pedido. Por sua vez, a autora interpôs recurso de apelação, ao qual, por unanimidade, foi dado parcial provimento pela Quinta Câmara Cível do TJ/RJ, para condenar as apeladas a procederem à instalação de filtros ou outro mecanismo que desvincule o nome da apelante das notícias relativas à suposta fraude.

As demandadas, então, interpuseram recursos especiais, os quais, em suma, alegaram que: a) a ação não seria útil ou necessária aos fins perseguidos, uma vez que o conteúdo repudiado pela autora permaneceria existindo nos sites de origem; b) tratar-se-ia de obrigação tecnicamente impossível, bem como ser imprescindível a indicação precisa da URL que a autora pretendia que fosse excluída dos resultados de indexação dos servidores e; c) a informação repudiada não representaria violação da vida privada ou à intimidade da autora, dizendo respeito a acontecimento público e revestido de interesse público.

Assim, em 22/08/2017, o feito foi levado a julgamento pela Terceira Turma do STJ, tendo a Relatora, Ministra Nancy Andrighi, prolatado seu voto, o qual deu provimento aos recursos especiais, mas que, como será visto mais adiante, acabou se tornando voto vencido.

A Relatora afirmou que o acórdão recorrido fora fundamentado no chamado direito ao esquecimento e ressaltou que o Brasil não dispunha, à época, de uma lei geral de proteção de dados pessoais ${ }^{2}$.

Argumentou que o STJ tem reconhecido o direito ao esquecimento, definindo-o como "o direito de não ser lembrado contra sua vontade, especificamente no tocante aos fatos desabonadores, de natureza criminal, nos quais se envolveu, mas que, posteriormente, fora

\footnotetext{
${ }^{1}$ BRASIL. STJ. Recurso Especial no 1.660.168 - RJ (2014/0291777-1). Recorrente: Yahoo! Do Brasil Internet Ltda. Recorrente: Google Brasil Internet Ltda. Recorrido: DPN. Interessado: Microsoft Informática Ltda. Relatora: Ministra Nancy Andrighi. Data de Julgamento: 08 maio 2018. Disponível em: https://ww2.stj.jus.br/processo/revista/documento/mediado/?componente=ITA\&sequencial=1628798\&num_r egistro=201402917771\&data=20180605\&formato=PDF. Acesso em: 01 abr. 2019.

2 Hoje, o Brasil já conta com uma Legislação de Proteção de Dados Pessoais, a Lei 13.709/2018, a qual encontra-se em vacatio legis até agosto de 2020.
}

80 | Revista do Programa de Pós-Graduação em Direito da UFBA, e-issn 2358-4777, v. 30, n. 01, p.78 -105, Jan-Jun 2020 
inocentado". No entanto, afirmou que, no âmbito digital, a jurisprudência do STJ é no sentido de que, por ausência de fundamento normativo, "os provedores de pesquisa não podem ser obrigados a eliminar do sistema os resultados derivados da busca de determinado termo ou expressão", pois imputar tal obrigação aos buscadores poderia transformá-los em censores digitais.

O voto continua afirmando que, na ausência de uma lei geral sobre a proteção de dados pessoais, deveria ser aplicado o Marco Civil da Internet (MCl), o qual, entende, somente assegura ao indivíduo o direito à exclusão dos dados pessoais que ele próprio tiver fornecido para um determinado provedor de aplicações de Internet, de modo que este direito não poderia ser garantido à autora, uma vez que esta não forneceu nenhuma informação aos provedores de busca ${ }^{3}$.

Feitas todas estas considerações, conclui que, imputar a um terceiro, que não detém de forma propriamente dita a informação, a função de retirar o acesso do público em geral de determinado conjunto de dados, no contexto normativo brasileiro, equivaleria a atribuir a "determinado tipo de provedor de aplicação de internet - no caso, os provedores de busca - a função de um verdadeiro censor digital, ${ }^{4}$ que vigiará o que pode ou não ser facilmente acessado pelo público em geral."

Depois da Ministra Relatora, o Ministro Marco Aurélio Bellizze proferiu seu voto, que viria a ser o vencedor, na sessão de 07/11/2017, inaugurando a divergência ao argumentar que existe todo um arcabouço legislativo que reflete a dimensão da proteção concreta à intimidade e privacidade, "a qual, em regra, cederá ao interesse público de conhecimento desses dados, tal

\footnotetext{
3 “No que tange à legislação ordinária, deve-se analisar a possível influência da publicação da Lei 12.965/2014, que institui o Marco Civil da Internet - $\mathrm{MCl}$. Como afirmado acima, não há no Brasil uma lei geral que disponha sobre a proteção de dados pessoais. Assim, o art. 7으, I e X, do $\mathrm{MCl}$ vem preencher parcialmente essa ausência legislativa, referente aos contornos do mencionado direito ao esquecimento [...].

Com relação aos provedores de aplicação de internet, a exclusão de dados pessoais é claramente um direito subjetivo que pode ser exercido sem qualquer condicionamento, exceto os casos de guarda obrigatória de registros.

Contudo, uma ponderação deve ser feita. Aplicações de internet são definidas no $\mathrm{MCl}$ como 'o conjunto de funcionalidades que poder ser acessadas por meio de um terminal conectado à internet'. Assim, o direito à exclusão mencionado acima alcança somente as informações que o próprio indivíduo houver fornecido para um determinado provedor de aplicações de Internet." (BRASIL. STJ. Recurso Especial no 1.660.168 - RJ (2014/0291777-1). Recorrente: Yahoo! Do Brasil Internet Ltda. Recorrente: Google Brasil Internet Ltda. Recorrido: DPN. Interessado: Microsoft Informática Ltda. Relatora: Ministra Nancy Andrighi. Data de Julgamento: $08 \quad$ maio 2018.2 Disponível em: https://ww2.stj.jus.br/processo/revista/documento/mediado/?componente=ITA\&sequencial=1628798\&num_r egistro=201402917771\&data=20180605\&formato=PDF. Acesso em: 01 abr. 2019, p. 14-15).

${ }^{4} \mathrm{Em}$ pesquisa realizada diretamente na ferramenta de busca de jurisprudência disponibilizada pelo site do STJ, em 14/07/2019, utilizando a expressão "censor digital", foram encontrados 02 acórdãos e 05 decisões monocráticas.

Em relação aos acórdãos, o primeiro é o acórdão já mencionado no texto. Já o segundo acórdão se refere ao AgInt no REsp 1593873/SP, relatado pela Ministra Nancy Andrighi, julgado em 10/11/2016, no qual a expressão é utilizada no seguinte contexto: "Ausência de fundamento normativo para imputar aos provedores de aplicação de buscas na internet a obrigação de implementar o direito ao esquecimento e, assim, exercer função de censor digital".

No que diz respeito às decisões monocráticas, tratam-se do AREsp 1481548, relatado pelo Min. Raul Araújo, EDcl no AREsp 1329335 e AREsp 1329335 relatados pela Min. Maria Isabel Gallotti, AREsp 1214401, relatado pelo Min. Marco Aurélio Bellizze e, ainda, o AgInt no REsp 878344, relatado pelo Min. Marco Buzzi. Em todos os casos, a expressão "censor digital" foi utilizada em referência a uma possível função a ser exercida pelos provedores de buscas na internet em relação à implementação do direito ao esquecimento, a qual, segundo entendimento dos Ministros, não encontra fundamento normativo.
}

81 | Revista do Programa de Pós-Graduação em Direito da UFBA, e-issn 2358-4777, v. 30, n. 01, p.78 -105, Jan-Jun 2020 
como ocorre no interesse de informar e na manutenção de informações relacionadas à memória histórica", no qual poderia ser apoiada a pretensão autoral.

Entretanto, o Ministro afirma que, em nossa Carta Magna, a tutela da proteção de dados é garantida pelo habeas data, quando, na verdade, esse é apenas um instrumento de garantia previsto na Constituição, havendo disposição constitucional que protege à intimidade e a vida privada do indivíduo, bem como a cláusula geral de proteção da personalidade que poderiam ser aplicadas ao caso concreto.

$O$ voto segue afirmando que o artigo $11^{5}$, do Marco Civil da Internet seria o fundamento legal que permite imputar aos provedores de busca a obrigação pleiteada pela autora, ressaltando que o Poder Judiciário deve apreciar casos concretos excepcionais que denotem a ausência de razoabilidade na exibição dos resultados. Nesse sentido, argumenta que:

Essa desproporcionalidade pode advir do conteúdo cujo interesse seja essencialmente privado e particular, de modo a escapar ao interesse coletivo de informação. Assim, também, pode resultar do longo prazo decorrido desde o fato que deu ensejo à inclusão dos dados pessoais apontados na busca.

Continua seu voto argumentando que a essência desse direito não é apagar o passado, mas "permitir que a pessoa envolvida siga sua vida com razoável anonimato, não sendo o fato desabonador corriqueiramente rememorado e perenizado por sistemas automatizados de busca." ${ }^{6}$.

Ressalta que aqueles que quiserem ter acesso a informações relativas a fraudes em concurso público, não terão seu direito de acesso impedido, já que pela desindexação nenhuma página é excluída da web. "Contudo, sua busca deverá conter critérios relativos a esse conteúdo, seja em conjunto com o nome da recorrida, seja de forma autônoma.", de modo que são conciliados o livre acesso à informação e o legítimo interesse individual.

Assim, afirma que o será evitado é tão somente que a busca de informações "sobre a sua pessoa, por meio da inclusão de seu nome como critério exclusivo de busca, tenha por resultado a indicação do fato desabonador noticiado há uma década, impedindo a superação daquele momento" ${ }^{7}$.

\footnotetext{
${ }^{5}$ Art. 11. Em qualquer operação de coleta, armazenamento, guarda e tratamento de registros, de dados pessoais ou de comunicações por provedores de conexão e de aplicações de internet em que pelo menos um desses atos ocorra em território nacional, deverão ser obrigatoriamente respeitados a legislação brasileira e os direitos à privacidade, à proteção dos dados pessoais e ao sigilo das comunicações privadas e dos registros. [...].

${ }^{6}$ Importa dizer, aqui, que a demanda ora analisada versa sobre direito à desindexação, o qual, como será discutido mais adiante, é uma categoria do direito ao esquecimento. Entretanto, durante todo o julgamento, direito ao esquecimento e direito à desindexação são utilizados como expressões sinônimas.

${ }^{7}$ A respeito de outras decisões do STJ sobre o direito à desindexação, uma pesquisa realizada na ferramenta de busca de jurisprudência disponibilizada pelo STJ buscando pela expressão "direito ao esquecimento" foram encontrados 23 acórdãos, com julgamento a partir de 01/01/2011, dos quais, 17 tratavam de direito ao esquecimento no âmbito penal, sendo a maioria, especificamente, sobre direito à reabilitação, 3 versavam sobre o direito ao esquecimento relacionado a matérias em jornal impresso e documentários de TV e apenas 3 diziam respeito ao direito ao esquecimento na internet: REsp 1660168/RJ, AgInt no REsp 1593873/SP e AgInt no REsp 1599054/RJ. Já quando se buscou pelo termo "desindexação", também a partir de 01/01/2011, a jurisprudência do STJ apresentou apenas 03 resultados, os quais se referem à desindexação de valores econômicos.
}

82 | Revista do Programa de Pós-Graduação em Direito da UFBA, e-issn 2358-4777, v. 30, n. 01, p.78 -105, Jan-Jun 2020 
Após o voto do Ministro Marco Aurélio Bellizze, a Ministra Relatora, em 21/11/2017, reafirmou o voto que havia originalmente proferido, enfatizando que o artigo 11, do Marco Civil da Internet, somente diz respeito à competência legal e judicial brasileira por tráfego de dados, sendo uma cláusula de jurisdição.

Em seguida, reafirma que a pretensão autoral de que os provedores de busca façam a filtragem dos resultados de busca recai no que o STJ reiteradamente tem entendido como censura $^{8}$, o que não pode ser admitido, argumentando que um precedente estabelecido há anos só deve ser afastado quando a excepcionalidade da hipótese o justificar, o que não verificou no caso, uma vez que o conteúdo não era ilícito, bem como a autora não teria arguido que a situação foi capaz de causar dano a sua pessoa.

Prossegue relatando que a suposta fraude foi noticiada por diversos órgãos, inclusive do Senado Federal e do próprio Poder Judiciário, por meio dos sites do CNJ, do STF, de modo que, caso concedido o pleito autoral, estaria sendo permitido que os provedores de busca censurassem ou bloqueassem conteúdos disponíveis em sites do próprio Poder Judiciário, o que não faria sentido. Nesse sentido, entende que a prestação jurisdicional pugnada é de pouca utilidade, haja vista que a ação gera mais notícias e conteúdos na internet acerca do fato e mais usuários compartilhando, o que inviabilizaria sua localização e remoção.

Por fim, assevera que o entendimento do STJ é no sentido de que o cumprimento da remoção preventiva de conteúdo ilegal ou ofensivo fica condicionado à indicação do URL, faltando ao acórdão recorrido elemento essencial de validade, qual seja a identificação inequívoca de quais informações devem ser censuradas.

Seguindo-se ao aditamento ao voto pela Ministra Relatora, o Ministro Moura Ribeiro, em 06/03/2018, proferiu voto acompanhando a divergência.

Iniciou argumentando que o enunciado 531, do CJF, reconhece que, muito embora não esteja positivado em nosso ordenamento jurídico, o direito ao esquecimento é um dos direitos da personalidade, sendo um direito implícito decorrente da pela tutela da dignidade da pessoa humana na sociedade da informação.

\footnotetext{
${ }^{8}$ Em 14/07/2019, ao se pesquisar no buscador do STJ as expressões "Filtragem Prévia" e "Internet", restringindo-se a busca a decisões proferidas após 01/01/2011, foram encontrados 09 acórdãos, dos quais dois merecem ser destacados:

REsp 1679465/SP - Rel. Min. Nancy Andrihi, “Reitera-se que os provedores de busca não devem fazer censura prévia do conteúdo dos links apresentadas nos resultados da pesquisa. [...]. A peculiaridade que deve ser ressaltada relaciona-se com a natureza do conteúdo divulgado na internet: cuida-se de vídeo que contém cenas de nudez e de conotação sexual de caráter totalmente privado da recorrida, cuja divulgação ocorreu sem nenhuma autorização por parte dela". BRASIL. Superior Tribunal de Justiça (3. Turma). AgInt no REsp 1593873/SP. Recorrente: Google Brasil Internet Ltda. Recorrido: S. M. S. Relatora: Min. Nancy Andrighi, 19 mar. 2018. Disponível em: http://twixar.me/0qM1. Acesso em: 09 jul. 2019, p. 10-11.

AgInt no REsp 1593873/SP - Rel. Min. Nancy Andrighi, "A legislação mencionada acima não permite imputar a um terceiro - que não detém de forma propriamente dita a a informação que se quer ver esquecida - cumprir a função [de] retirar o acesso do público em geral de determinado conjunto de dados. Concordar com tal situação, no contexto normativo brasileiro, equivale a atribuir a um determinado provedor de aplicação de internet - no caso, o buscador Google - a função de um verdadeiro censor digital, que vigiará o que pode ou não ser facilmente acessado pelo público em geral, na ausência de qualquer fundamento legal" BRASIL. Superior Tribunal de Justiça (3. Turma). AgInt no REsp 1593873/SP. Recorrente: Google Brasil Internet Ltda. Recorrido: S. M. S. Relatora: Min. Nancy Andrighi, 19 mar. 2018. Disponível em: http://twixar.me/0qM1. Acesso em: 09 jul. 2019, p. 15-16.

Além desses, os outros julgados também entenderam não ser possível a imposição aos provedores de busca de realizarem filtragem prévia em seus resultados: AgInt no AREsp 1227394/SP; AREsp 879704/SP; Rcl 5072/AC; Resp 1316921/RJ.
}

83 | Revista do Programa de Pós-Graduação em Direito da UFBA, e-issn 2358-4777, v. 30, n. 01, p.78 -105, Jan-Jun 2020 
Continua, afirmando que há base legal em nosso ordenamento jurídico para a pretensão autoral, contudo, mesmo que não houvesse, uma vez que é direito fundamental, a erga omnes do direito ao esquecimento "impõe a todos o seu direcionamento. Os provedores de busca, portanto, não podem se furtar ao respeito desse direito".

Por fim, afirma, ainda, que o pedido de desindexação garante o direito de informar e ser informado, já que não exclui as páginas da internet, ao mesmo tempo em que preserva a imagem da autora, "permitindo que ela siga sua vida e sua carreira sem ser constantemente vinculada à suspeita de participação de fraude que inexistiu.".

O Ministro Ricardo Villas Bôas Cueva, então, em 20/03/2018, proferiu voto acompanhando a Relatora.

Argumentou que o pedido autoral não é necessário nem eficaz, uma vez que entende que o conteúdo ofensivo ao direito da autora de ser esquecida não é de responsabilidade dos recorrentes, mas de terceiros, motivo pelo qual as publicações continuarão sendo facilmente acessadas, "inclusive a partir da simples utilização do nome da autora como parâmetro de pesquisa em serviços dessa natureza oferecidos por outros provedores de aplicações".

Em seguida, concorda com a Relatora, entendendo que "os provedores de pesquisa não podem ser obrigados a eliminar do seu sistema os resultados da busca de determinado termo ou expressão", bem como que é indispensável a indicação da URL no pedido, ${ }^{9}$ não sendo dispensada esta exigência nem mesmo nos casos de violação da intimidade decorrentes da divulgação de cenas de nudez ou de atos sexuais de caráter privado.

Afirma, ainda, não existir, no caso em apreço, qualquer excepcionalidade que justifique decisão contrária à orientação jurisprudencial do STJ.

Em seguida, o Ministro Bellize reafirmou seu voto, ao argumentar que não há impossibilidade fática para o cumprimento da obrigação pleiteada, bem como que, no exame harmonioso de todo o nosso sistema jurídico, bem como num juízo de ponderação de regras jurídicas de mesma estatura, a proteção à intimidade deve preponderar no exame do caso concreto e de suas peculiaridades.

O Ministro Paulo de Tarso Sanseverino, então, em 08/05/2018, proferiu seu voto acedendo às conclusões do Ministro Marco Aurélio Bellize por também não vislumbrar ausência de base legal para apoiar a pretensão autoral.

Nesse sentido, afirmou que, mesmo antes do Marco Civil da Internet, o STJ já admitia o direito ao esquecimento, entendido como "verdadeira faceta de dois direitos fundamentais (dignidade da pessoa humana e privacidade)".

Afirmou, ainda, existirem "diversos casos de danos decorrentes das novas tecnologias de informação colocadas à disposição dos cidadão, que precisam ser analisadas, caso a caso, sob pena de o direito não acompanhar a evolução tecnológica".

Em seguida, argumentou que todos os precedentes do STJ, até então, versam acerca de ações ajuizadas contra provedores de busca que requerem a exclusão definitiva da internet de conteúdos ofensivos resultantes de pesquisas realizadas com o nome dos autores ou com

\footnotetext{
${ }^{9}$ Uma busca realizada em 14/07/2019 na ferramenta de jurisprudência do site do STJ pelo termo "Indicação da URL", tendo como marco inicial 01/01/2011, apresentou 07 resultados, sendo que um deles não tinha relação com o termo pesquisado (AgRg no REsp 533836/MG). Entre os demais acórdãos, a maioria faz referência tanto a jurisprudência do STJ quanto ao Marco Civil da Internet como fundamentos para a exigência de indicação de URL do conteúdo infringente (AgInt no AgInt no AREsp 956396/MG, REsp 1642560/SP, REsp 1629255/MG, AgRg no REsp 1384340/DF). Há, ainda, um resultado que aponta a necessidade de indicação da URL como fato anterior ao Marco Civil da Internet (REsp 1738628/SE) e um acórdão que aponta essa exigência como sendo previsão do Marco Civil da Internet, sem fazer menção a precedentes do STJ (REsp 1568935/RJ).
}

84 | Revista do Programa de Pós-Graduação em Direito da UFBA, e-issn 2358-4777, v. 30, n. 01, p.78 -105, Jan-Jun 2020 
determinados termos de pesquisa e que direcionavam os resultados para as páginas que pretendiam excluir, de modo que são situações que diferem do caso em análise.

Por fim, concluiu que a autora está sofrendo dano à honra e à intimidade, estando o seu pedido perfeitamente abarcado pelo direito ao esquecimento, de modo que "Na tensão que se coloca entre o direito fundamental à informação e as liberdades públicas dos cidadãos, ao meu ver, o primeiro deve ceder."

Com esse voto, venceu a posição avençada pelo Ministro Marcos Aurélio Bellizze, mantendo-se o Acórdão do TJ/ RJ que determinou à Google, à Yahoo e à Microsoft a "implantação de filtro por palavra-chave com escopo de evitar a associação do nome da autora a notícias que envolvam suposta fraude no XLI Concurso da Magistratura" do Estado do Rio de Janeiro.

Apresentado o caso e as diferentes perspectivas dos julgadores, cumpre-nos investigar como o pedido da autora é visto, atualmente, pela doutrina, legislação e jurisprudência pátrias, de modo a verificar se a pretensão autoral é compatível com o ordenamento jurídico brasileiro. 
3 Direito ao Esquecimento e Direito à Desindexação: análise da pretensão da autora no RESP $1660168 /$ RJ

Como visto, a autora ingressou com obrigação de fazer em face dos provedores de busca a fim de obrigá-los a omitirem de seus resultados aqueles que fossem relacionados à suposta fraude quando realizadas pesquisas utilizando, como parâmetro, apenas seu nome.

O caso em análise diz respeito ao direito à desindexação. Importa dizer que, muito embora, a decisão tenha tratado as expressões como sinônimas, direito ao esquecimento e direito à desindexação são diferentes. Isso porque, o direito à desindexação pode ser compreendido como uma categoria do direito ao esquecimento, por conseguinte, estes direitos possuem alcances distintos. ${ }^{10}$

Voss e Castets-Renard afirmam que o direito ao esquecimento abrange cinco categorias, as quais se diferenciam pela dimensão da proteção ou campo de aplicação, quais sejam: 1. Direito de reabilitação, que seria o direito ao esquecimento do passado judicial; 2. Direito de apagamento, isto é, a possibilidade de apagar dados, de acordo com a previsão das legislações de proteção de dados; 3 . Direito à desindexação, o qual será tratado mais adiante; 4. Direito à obscuridade pelo qual as informações não seriam apagadas ou desindexadas, mas seriam aplicadas técnicas que tornassem dificultassem os dados de serem encontrados na rede, de modo que os dados ficariam obscuros e; 5 . Direito ao esquecimento dos dados recolhidos na sociedade da informação, pelo qual as informações compartilhadas teriam uma data de expiração. ${ }^{11}$

Isso posto, o direito ao esquecimento pode ser entendido como "[...] o direito de uma determinada pessoa não ser obrigada a recordar, ou ter recordado certos acontecimentos de sua vida"12. Ao passo que a desindexação é a exclusão dos resultados de buscas dos provedores de pesquisa de hyperlinks que direcionam os usuários a páginas da internet que apresentem conteúdos irrelevantes ou desatualizados sobre o indivíduo ${ }^{13}$. A desindexação é, hoje, a forma mais atual do direito ao esquecimento na sociedade da informação.

Feitas estas considerações, importa, agora, analisar se a pretensão da autora encontra respaldo em nosso ordenamento jurídico.

10 Para um estudo mais aprofundado sobre as diferenças entre direito ao esquecimento e direito à desindexação e seus respectivos alcances ver EHRHARDT JÚNIOR, Marcos A. A; ACIOLI, Bruno L. Uma agenda para o direito ao esquecimento no Brasil. In: Revista Brasileira de Políticas Públicas - Direito e mundo digital, v. 7, n. 3, dez. 2017, p. 399. Disponível em: https://www.publicacoes academicas.uniceub.br/RBPP/article/view/4867/3671. Acesso em: 28 mar. 2019.

${ }^{11}$ VOSS, W. Gregory; CASTETS-RENARD, Céline Casters. Proposal for na international taxonomy on the various forms of the "Right to be Forgotten": a study on the convergence of norms. Colo Tech L. J., v. 14, n. 2, p. 298, 23 maio 2016. Disponível em: https://ctlj.colorado.edu/wp-content/uploads/2016/06/v.3-final-Voss-andRenard-5.24.16.pdf. Acesso em: 09 jul. 2019.

${ }^{12}$ CORREIA JÚNIOR, José B. 2015, p. 22 apud EHRHARDT JÚNIOR, Marcos A. A; ACIOLI, Bruno L. Uma agenda para o direito ao esquecimento no Brasil. In: Revista Brasileira de Políticas Públicas - Direito e mundo digital, v. 7, n. 3, dez. 2017, p. 386. Disponível em: https://www.publicacoes academicas.uniceub.br/RBPP/article/view/4867/3671. Acesso em: 01 abr. 2019.

${ }^{13}$ ACIOLI, Bruno L. O Direito ao Esquecimento e o Livre Fluxo de Informações na Internet: reconhecimento, aplicação e efetividade deste direito no Brasil. 2018. Dissertação (Mestrado em Direito) - Faculdade de Direito de Alagoas, Universidade Federal de Alagoas, Maceió. Disponível em: http://twixar.me/YkM1. Acesso em: 22 mar. 2019, p. 61.

86 | Revista do Programa de Pós-Graduação em Direito da UFBA, e-issn 2358-4777, v. 30, n. 01, p.78 -105, Jan-Jun 2020 
Consoante Anderson Schreiber ${ }^{14}$, existem três correntes sobre o direito ao esquecimento. A primeira corrente, denominada de posição pró-informação, para quem não o direito ao esquecimento não existe, uma vez que, além de não constar expressamente da legislação brasileira, não poderia ser extraído de nenhum outro direito fundamental. Para essa posição, defendida por diversas entidades ligadas à comunicação, a liberdade de informação prevaleceria sempre a priori.

Por sua vez, a segunda corrente, chamada de posição pró-esquecimento, entende que o direito ao esquecimento existe e deve preponderar sempre, mesmo sobre a liberdade de informação, haja vista que é expressão do direito da pessoa humana à reserva, à intimidade e à privacidade. Essa posição é defendida pelo Instituto Brasileiro de Ciências Criminais (IBCCim).

Por fim, a terceira corrente é a posição intermediária, para quem a Constituição brasileira não permite hierarquização prévia e abstrata entre liberdade de informação e privacidade, da qual o direito ao esquecimento seria um desdobramento. Dessa forma, ambos os direitos deveriam ser ponderados sempre que entrassem em colisão. Esta posição é a defendida pelo Instituto Brasileiro de Direito Civil (IBDCivil).

O autor ainda faz uma ressalva importante, a de que o termo "direito ao esquecimento" não é o mais adequado, por sugerir um apagar da História e por não corresponder ao significado técnico por trás da expressão, consubstanciado na tutela "da identidade pessoal e do direito de toda pessoa humana de ser corretamente retratada em suas projeções públicas, além de tangenciar diversas outras questões polêmicas", como a indexação de resultados por motores de busca da internet e a tutela post mortem do direito à imagem ${ }^{15}$.

Nesse cenário, Sarlet afirma que o direito ao esquecimento, na ordem constitucional brasileira, constitui um direito fundamental de natureza implícita, sendo uma manifestação da dignidade da pessoa humana e do direito ao livre desenvolvimento da personalidade, bem como guardando relação, ainda, com diversos direitos de personalidade, como os direitos à privacidade, intimidade, honra e imagem, além do direitos à autodeterminação informativa, ao nome e o direito à identidade pessoal, todos já reconhecidos pelo $\mathrm{STF}^{16}$.

A seu turno, Bucar afirma que o direito ao esquecimento está inserido na disciplina de proteção à privacidade, cuja tutela, em aspectos gerais, é extraída dos artigos 50, X, XI e XII, da Constituição da República e 21 do Código Civil. O chamado direito ao esquecimento incorpora uma expressão do controle temporal de dados, que preenche com o fator cronológico a atual tríade de ferramentas protetivas da privacidade, complementada pelos controles espacial e contextual ${ }^{17}$.

Já para Sarmento, o reconhecimento do direito ao esquecimento no sentido de impedir a divulgação, discussão ou encenação de fatos de interesse público ocorridos no passado, em qualquer veículo ou plataforma, cuja recordação seja embaraçosa, prejudicial ou dolorosa para

\footnotetext{
${ }^{14}$ SCHREIBER, Anderson. As três correntes do direito ao esquecimento. Jota - Opinião \& Análise, 18 jun. 2017. Disponível em: https://www.jota.info/paywall?redirect_to=// www.jota.info/opiniao-e-analise/artigos/as-trescorrentes-do-direito-ao-esquecimento-18062017. Acesso em: 09 jul. 2019.

${ }^{15}$ SCHREIBER, Anderson. As três correntes do direito ao esquecimento. Jota - Opinião \& Análise, 18 jun. 2017. Disponível em: https://www.jota.info/paywall?redirect_to=// www.jota.info/opiniao-e-analise/artigos/as-trescorrentes-do-direito-ao-esquecimento-18062017. Acesso em: 09 jul. 2019.

${ }^{16}$ SARLET, Ingo Wolfgang. Proteção da Personalidade no Ambiente Digital: uma análise a luz do caso do assim chamado Direito ao Esquecimento no Brasil. Espaço Jurídico Journal of Law (EJIL), Joaçaba, v. 19, n. 2, p. 498, maio/ago. 2018. Disponível: https://portalperiodicos.unoesc.edu.br/espacojuridico/article/view/17557. Acesso em: 09 jul. 2019.

${ }^{17}$ BUCAR, Daniel. Controle temporal de dados: o direito ao esquecimento. Civilista.com, ano 2, n. 3, p. 7, 2013. Disponível em: http://civilistica.com/wp-content/uploads/2015/02/ Bucar-civilistica.com. Acesso em: 09 jul. 2019.
}

87 | Revista do Programa de Pós-Graduação em Direito da UFBA, e-issn 2358-4777, v. 30, n. 01, p.78 -105, Jan-Jun 2020 
alguém não é compatível com a atual Constituição Federal, pelas ameaças que encerra às liberdades comunicativas, à História e à memória coletiva, as quais ostentam prioridade prima facie em casos de colisão com outros princípios, de modo que as restrições que lhes são impostas estão sujeitas a uma série de requisitos, que o direito ao esquecimento não atende ${ }^{18}$.

Entretanto, o autor reconhece um espaço legítimo para que o direito ao esquecimento seja protegido sem representar risco tão significativo para a liberdade de comunicação e a memória coletiva, qual seja, o campo da proteção dos dados pessoais despidos de interesse público. Isso porque, em virtude dos avanços tecnológicos, instituições estatais e privadas coletam, armazenam, tratam e divulgam uma grande quantidade de informações sobre as pessoas, o que aumenta a vulnerabilidade dos indivíduos, sendo necessário, portanto, construir instrumentos jurídicos que permitam às pessoas o exercício de algum controle sobre os seus dados pessoais que não tenham interesse público. Assim, "Embora a designação não pareça a mais apropriada, o "direito ao esquecimento" encontra aqui um campo legítimo para desenvolvimento, do ponto de vista dos valores jurídicos e morais envolvidos." ${ }^{19}$.

As reservas que surgem em torno do reconhecimento do direito ao esquecimento são porque, como comenta Paul Bernal ${ }^{20}$, enquanto na Europa o direito ao esquecimento é visto como uma extensão lógica das leis de proteção de dados pessoais, para os americanos, este direito é visto como uma ameaça à liberdade de expressão. Também no continente americano, máxime em razão do histórico recente de sistemas ditatoriais, há muita desconfiança de que este direito acabe se tornando um instrumento de censura ${ }^{21}$.

O enunciado 531, da VI Jornada de Direito Civil, afirma que "a tutela da dignidade da pessoa humana na sociedade da informação inclui o direito ao esquecimento" ${ }^{22}$. Nessa esteira, como bem exposto pelo Ministro Moura Ribeiro, a despeito de não estar positivado, o direito ao esquecimento é um dos direitos da personalidade, sendo um direito implícito, isto é, extraído do texto constitucional, que decorre da tutela da dignidade da pessoa humana.

Importa dizer que a Constituição Federal brasileira não positivou todos os direitos fundamentais, contudo, isso não quer dizer que não existem direitos fundamentais além dos expressos na Carta Magna, haja vista é possível depreender, de seu texto, outros direitos, os chamados direitos fundamentais implícitos. Dessa feita, há, em nosso ordenamento jurídico, uma cláusula geral de tutela da pessoa humana que permite "estender a tutela a situações não previstas" $^{23}$. Assim, existem também direitos da personalidade implícitos, isto é, que não estão

18 SARMENTO, Daniel. Liberdades comunicativas e "Direito ao Esquecimento" na ordem constitucional brasileira. Revista Brasileira de Direito Civil, v. 7, p. 226-231, jan./mar. 2016. Disponível em: https://rbdcivil.ibdcivil.org.br/rbdc/article/view/76. Acesso em: 09 jul. 2019.

19 SARMENTO, Daniel. Liberdades comunicativas e "Direito ao Esquecimento" na ordem constitucional brasileira. Revista Brasileira de Direito Civil, v. 7, p. 226-227, jan./mar. 2016. Disponível em: https://rbdcivil.ibdcivil.org.br/rbdc/article/view/76. Acesso em: 09 jul. 2019.

${ }^{20}$ BERNAL, Paul, 2014, p. 61 apud EHRHARDT JÚNIOR, Marcos A. A; ACIOLI, Bruno L. Uma agenda para o direito ao esquecimento no Brasil. Revista Brasileira de Políticas Públicas - Direito e mundo digital, v. 7, n. 3, dez. 2017, p. 399. Disponível em: https://www.publicacoes academicas.uniceub.br/RBPP/article/view/4867/3671. Acesso em: 01 abr. 2019.

${ }^{21}$ EHRHARDT JÚNIOR, Marcos A. A; ACIOLI, Bruno L. Uma agenda para o direito ao esquecimento no Brasil. Revista Brasileira de Políticas Públicas - Direito e mundo digital, v. 7, n. 3, dez. 2017, p. 399. Disponível em: https://www.publicacoes academicas.uniceub.br/RBPP/article/view/4867/3671. Acesso em: 01 abr. 2019.

22 BRASIL. CJF. VI Jornada de Direito Civil. Enunciado 531. 2013. Disponível em: https://www.cjf.jus.br/enunciados/enunciado/142. Acesso em: 01 abr. 2019.

23 EHRHARDT JÚNIOR, Marcos A. A; TORRES, Marcio R. Direitos Fundamentais e as Relações Privadas. Superando a (pseudo) tensão entre aplicabilidade direta e eficácia indireta para além do patrimônio. In: Curitiba: Revista Jurídica, v. 04 , n. 53, 2018, p. 343. Disponível em: http://revista.unicuritiba.edu.br/index.php/RevJur/article/view/ 3222/371371738. Acesso em: 01 abr. 2019.

88 | Revista do Programa de Pós-Graduação em Direito da UFBA, e-issn 2358-4777, v. 30, n. 01, p.78 -105, Jan-Jun 2020 
expressamente previstos em nosso ordenamento. Nessa esteira, sendo o direito ao esquecimento um direito da personalidade, é possível reconhecê-lo, apesar de não estar positivado ${ }^{24}$.

Não é um direito da personalidade autônomo e, embora as divergências doutrinárias expostas, o direito ao esquecimento decorre do direito à privacidade enquanto direito à autodeterminação informativa ${ }^{25}$, entendida esta como "o direito de manter o controle sobre suas próprias informações e de determinar a maneira de construir a sua própria esfera particular" ${ }^{\prime 26}$.

A noção inicial de direito ao esquecimento estava ligada à passagem do tempo, como no direito de esquecer o passado criminal de alguém que já cumpriu a pena à qual foi condenado. No entanto, como ensina Terwagne ${ }^{27}$, ao menos na Europa e no Brasil, atualmente o direito ao esquecimento é visto muito mais como uma forma de exercício do direito do indivíduo à autodeterminação informativa.

Acerca disso, Anderson Schreiber ${ }^{28}$ afirma que:

se toda pessoa tem direito a controlar a coleta e uso de seus dados pessoais, deve-se admitir que tem também o direito de impedir que dados de outrora sejam revividos na atualidade, de modo descontextualizado, gerando-Ihe risco considerável.

Não é difícil perceber que a disseminação de informações, ainda que verdadeiras, podem provocar um dano à privacidade do indivíduo, uma vez que afeta a sua maneira de construir sua esfera particular.

Na sociedade da informação, não são raras as pesquisas feitas na internet com o intuito de descobrir um pouco mais sobre alguém de quem, até então, somente se sabe o nome. Os motivos para isso são os mais variados e podem ir desde a simples curiosidade até a razões que podem influenciar diretamente a vida da pessoa pesquisada, como no caso de empresas que investigam um candidato a vaga de emprego. Dois casos ilustram bem essa questão.

Imagine todas as consequências nefastas sofridas por uma pessoa que teve fotos íntimas divulgadas na internet, de modo que, quando alguém pesquisa o seu nome nos provedores de busca, os primeiros resultados retornados são as páginas que contém essas imagens de nudez. É

\footnotetext{
${ }^{24}$ MORAES, Marina Celina Bodin de. Danos à Pessoa Humana: uma Leitura Civil-Constitucional dos Danos Morais. Rio de Janeiro: Renovar, 2003, p. 117-118.

${ }^{25}$ BUCAR, Daniel. Controle temporal de dados: o direito ao esquecimento. Civilista.com, ano 2, n. 3, p. 10, 2013. Disponível em: http://civilistica.com/wp-content/uploads/2015/02/Bucar-civilistica.com. Acesso em: 09 jul. 2019.

${ }^{26}$ PEIXOTO, Erick L. C; EHRHARDT JÚNIOR, Marcos. Breves notas sobre a ressignificação da privacidade. In: Belo Horizonte: Revista Brasileira de Direito Civil, v. 16, abr./jun. 2018, p. 42. Disponível em: https://rbdcivil.ibdcivil.org.br/rbdc/article/view/230/212. Acesso em: 01 abr. 2019.

27 DE TERWANGNE, Cecile. The Right to be Gorgotten and the Informational Autonomy in the Digital Environment. European Comission, Luxemburgo: Escritório de Publicações da União Européia, p. 5, 2013. Disponível em: https://ec.europa.eu/jrc/en/ publication/right-be-forgotten-and-informational-autonomydigital-environment. Acesso em: 09 jul. 2019.

28 SCHREIBER, 2011, p. 164 apud BRANCO, Sérgio. Memória e Esquecimento na Internet. Porto Alegre: Arquipélago Editorial, 2017, p. 142.
}

89 | Revista do Programa de Pós-Graduação em Direito da UFBA, e-issn 2358-4777, v. 30, n. 01, p.78 -105, Jan-Jun 2020 
patente que esses resultados de busca causam graves danos aos direitos da personalidade dessa pessoa. Essa foi a demanda analisada no Resp no $1.593 .873-\mathrm{SP}^{29}$.

A autora requereu que o Google não retornasse nenhum resultado de buscas realizadas com seu nome, já que isso poderia levar às páginas que continham essas imagens. Em primeira instância, o processo foi extinto sem resolução do mérito. Por sua vez, o Tribunal de Justiça de São Paulo deferiu o pedido, argumentando que o conteúdo disseminado na Internet não era de interesse público, mas circunscrito à vida privada da pessoa exposta.

Entretanto, a Terceira Turma do STJ, entendeu que os provedores de busca a) não respondem pelo conteúdo do resultado das buscas realizadas por seus usuários; b) não podem ser obrigados a exercer um controle prévio do conteúdo dos resultados das buscas feitas por cada usuário; e c) não podem ser obrigados a eliminar do seu sistema os resultados derivados da busca de determinado termo ou expressão.

A Terceira Turma aduziu, ainda, que o pedido deveria ter sido dirigido ao responsável pela hospedagem/disponibilização das fotos íntimas na internet, por entender que não há "fundamento normativo no ordenamento jurídico pátrio" apto a imputar aos provedores de aplicação de buscas na internet a implementação do direito ao esquecimento. Afirmou, ainda, que tal imputação atribuiria ao Google a função de sensor digital.

Em outro caso, a apresentadora de TV Xuxa Meneghel ingressou com uma ação contra o Google, ${ }^{30}$ na qual pleiteou a remoção dos resultados relativos às buscas realizadas pelo provedor de pesquisa que contivessem a expressão "Xuxa pedófila" ou qualquer outra busca associando o nome dela, escrito parcial ou integralmente, e independentemente da grafia, a alguma prática criminosa as realizadas no mecanismo de busca, ou seja, buscava o reconhecimento do direito de ser desindexada dos resultados do provedor de pesquisa. Também aqui não é difícil imaginar o tamanho da carga negativa que os resultados dessas buscas traziam para aquela que é considerada a rainha dos baixinhos. Ressalte-se aqui que era verídica a informação de que a apresentadora atuou no filme "Amor Estranho Amor" ao lado de um ator menor de idade, contudo, não era verdadeira a prática de pedofilia que the foi imputada, razão pela qual a associação de seu nome à expressão "pedófila" era ilícita.

Em primeira instância, em sede de tutela antecipada, o juízo determinou que o Google não disponibilizasse aos usuários quaisquer resultados referentes à busca pelas expressões "Xuxa", "pedófila", "Xuxa Meneghel", com essas ou outras grafias, isolada ou conjuntamente, com ou sem aspas, pelo período de 48 horas a contar da intimação. Contudo, o caso acabou chegando ao STJ e a Terceira Turma do Tribunal entendeu que não cabe impor aos buscadores qualquer restrição nos resultados das buscas realizadas por meio de seus provedores, independentemente da indicação da URL, pois, essa filtragem prévia violaria o direito constitucional à informação, portanto, negando à apresentadora o direito à desindexação. Ademais, afirmaram que "Não se pode, sob o pretexto de dificultar a propagação de conteúdo ilícito ou ofensivo na web, reprimir o direito da coletividade à informação".

Os casos apresentados demonstram que os resultados que os mecanismos de buscas apresentam podem causar danos a alguém, indexando resultados com informações desabonadoras desatualizadas, ainda que verídicas, mas que podem influenciar negativamente as conviç̧ões que o usuário formará sobre esta pessoa.

\footnotetext{
29 BRASIL. Superior Tribunal de Justiça (3. Turma). AgInt no REsp 1593873/SP. Recorrente: Google Brasil Internet Ltda. Recorrido: S. M. S. Relatora: Min. Nancy Andrighi, 19 mar. 2018. Disponível em: http://twixar.me/0qM1. Acesso em: 09 jul. 2019

${ }^{30}$ BRASIL. Superior Tribunal de Justiça (3. Turma). REsp 1316921/RJ. Recorrente: Google Brasil Internet Ltda. Recorrido: Maria da Graça Xuxa Meneghel. Relatora: Min. Nancy Andrighi, 26 jun. 2012. Disponível em: https://www.internetlab.org.br/wp-content/uploads/2017/02/STJ-REsp-1316921. Acesso em: 09 jul. 2019.
}

90 | Revista do Programa de Pós-Graduação em Direito da UFBA, e-issn 2358-4777, v. 30, n. 01, p.78 -105, Jan-Jun 2020 
No entanto, nas duas situações as autoras tiveram seus pedidos negados, uma vez que, até o julgamento da decisão analisada nesse trabalho, a jurisprudência do STJ era no seguinte sentido: os provedores de aplicação e conteúdo, incluindo as redes sociais e provedores de busca, não respondem objetivamente pela inserção no site, por terceiros, de informações ilegais, nem poderiam ser obrigados a exercer um controle prévio do conteúdo das informações postadas pelos usuários. Entretanto, teriam responsabilidade subjetiva, de modo que no momento em que tivessem inequívoca ciência da sua existência deveriam removê-los imediatamente, sob pena de responsabilização pelos danos causados. Além disso, o STJ exigia a indicação precisa pelo autor da ação do localizador URL do conteúdo tido como ilícito como condição para a obtenção da ordem judicial.

Essa exigência foi modificada com o julgamento ora em comento, no qual, embora a autora não tivesse indicado os links que pretendia ver desindexados, o Superior Tribunal de Justiça acolheu o pleito autoral para que os provedores de busca deixassem de apresentar, em seus resultados, notícias relacionadas à suposta fraude quando fossem realizadas pesquisas por meio de seu nome.

Assim, nos dois exemplos aqui expostos, o STJ negou o direito à desindexação, por entender que não havia fundamento legal no ordenamento jurídico pátrio para legitimar tal pretensão, o que demonstra a relutância do Tribunal em reconhecer esse direito. Entretanto, no julgamento analisado neste trabalho, o Tribunal reconheceu o direito à desindexação, mesmo sem a indicação da URL, entendendo ser possível que os buscadores de pesquisa implementassem filtros para que os resultados das pesquisas omitissem links que veiculassem a notícia de fraude em concurso.

No que diz respeito à decisão analisada neste trabalho, importa dizer que o Marco Civil, em seu artigo 19, dispõe que o provedor de aplicações de internet - e nessa categoria estão também os provedores de busca - poderá ser responsabilizado civilmente por danos decorrentes de conteúdo gerado por terceiros se, após ordem judicial específica, não tomar as providências para, no âmbito e nos limites técnicos do seu serviço e dentro do prazo assinalado, tornar indisponível o conteúdo apontado como infringente.

Dessa feita, já à época do julgamento havia previsão em legislação infraconstitucional a legitimar o direito da autora. No entanto, o Marco Civil exige a indicação da URL em casos como esse, o que não foi indicado pela autora, que ingressou com a ação antes da vigência dessa Lei e, talvez por isso, não o tenha feito.

Além disso, como visto, o direito ao esquecimento é um direito da personalidade que decorre do direito à privacidade, apesar de não estar previsto expressamente em nosso ordenamento jurídico, existindo uma cláusula geral de tutela da pessoa humana que permite estender tal proteção a situações não previstas. Dessa forma, há fundamento na própria Constituição Federal a amparar o pedido da autora. Também a doutrina brasileira, como demonstrado, reconhece o direito à desindexação.

Diante disso, o direito ao esquecimento pode ser reconhecido ainda que se trate de informações verídicas, quando a irrelevância ou desatualização da informação estiver causando ou puder vir a causar danos à pessoa, de modo que, não existindo, no caso, um direito à informação que, pelas suas peculiaridades, justifique a manutenção da informação, deve ser reconhecido o direito à desindexação dos hyperlinks que direcionem à informação.

Importa salientar que, na desindexação, o conteúdo das páginas é preservado, uma vez que estas não são excluídas, contudo, o seu acesso é dificultado. Isso porque os provedores de busca, como o Google, indexam as páginas da internet de acordo com as informações que estas contêm. Quando são realizadas pesquisas nestes mecanismos, os provedores de busca procuram em seus índices os termos de pesquisa utilizados e, então, exibem uma lista de resultados.

91 | Revista do Programa de Pós-Graduação em Direito da UFBA, e-issn 2358-4777, v. 30, n. 01, p.78 -105, Jan-Jun 2020 
Com a desindexação, determinada informação é retirada dos índices dos provedores de busca, de modo que seus resultados deixam de exibi-la. Assim, embora a informação continue existindo na rede mundial de computadores, já que a página na qual está o conteúdo que não se quer exibido não é apagada, o seu acesso será muito dificultado, pois para alguém acessá-lo deverá saber o endereço específico da página.

Uma vez que a página na qual está o conteúdo permanece na internet, aquele que é lesionado pelo conteúdo da informação desatualizada poderia solicitar ao dono do site que a informação fosse atualizada, como sugeriu o ministro Moura Ribeiro ${ }^{31}$. Caso a solicitação não fosse atendida, seria possível ingressar com uma ação de obrigação de fazer pleiteando essa atualização.

Por fim, ressalte-se que o direito à desindexação, que ora se analisa, é uma das formas de direito ao esquecimento que mais bem conseguem harmonizar o direito à privacidade com o direito à informação, já que retira os hyperlinks dos provedores de busca, mas mantém na internet a página na qual se encontra a informação.

\section{O Reconhecimento Constitucional e Infraconstitucional do Direito à Desindexação no Ordenamento Jurídico Brasileiro}

Feitas estas considerações acerca do direito ao esquecimento, passa-se agora a analisar os argumentos da decisão.

Como visto, o principal ponto de divergência entre os votos diz respeito à existência ou não de previsão normativa que permita imputar aos provedores de pesquisa a obrigação de retirar do acesso do público resultados provenientes de seus mecanismos de busca para garantir o direito ao esquecimento da autora.

Inicialmente, importante dizer que, como bem destacado no voto da Ministra Relatora Nancy Andrighi, a jurisprudência do STJ, até então, entendia que inexistia previsão na Lei do Marco Civil da Internet que permitisse imputar aos provedores de pesquisa a exclusão de links indexados nos resultados da busca, consoante se verifica no julgamento do Agravo Interno no Recurso Especial no 1.593.873/SP310 32 .

Interessante notar que todos os Ministros que participaram do julgamento, vencidos ou não, reconheceram que o direito ao esquecimento é um direito fundamental, decorrente da dignidade da pessoa humana e do direito à privacidade. Entretanto, embora os Ministros tenham entendido que a situação versava sobre um direito fundamental, o qual, portanto, poderia ser aplicado pelos Tribunais somente com base na cláusula geral de tutela da pessoa humana, a exceção do Ministro Moura Ribeiro, todos foram buscar o fundamento para seu voto na legislação infraconstitucional, em especial no Marco Civil da Internet.

Assim, por exemplo, a Ministra Nancy Andrighi, com fundamento no artigo 7으, X, dessa Lei, entendeu que o Marco Civil somente assegura ao indivíduo o direito à exclusão dos dados pessoais que o próprio indivíduo tiver fornecido a determinado provedor de aplicações, o que não era o caso, já que a autora não teria fornecido qualquer informação aos provedores de

\footnotetext{
${ }^{31}$ BRASIL. Superior Tribunal de Justiça. Recurso Especial no 1.660.168 - RJ (2014/0291777-1). Recorrente: Yahoo! Do Brasil Internet Ltda. Recorrente: Google Brasil Internet Ltda. Recorrido: DPN. Interessado: Microsoft Informática Ltda. Relatora: Ministra Nancy Andrighi. Data de Julgamento: 08 maio 2018. Disponível em: https://ww2.stj.jus.br/processo/revista/documento/mediado/?componente=ITA\&sequencial=1628798\&num_ registro=201402917771\&data=20180605\&formato=PDF. Acesso em: 22 mar. 2019. p. 51.

32 BRASIL. Superior Tribunal de Justiça. AgInt no Recurso Especial no 1.593.873 - SP (2016/0079618-1). Agravante: Google Brasil Internet Ltda. Agravado: SMS. Relatora: Ministra Nancy Andrighi, Brasília, 10 nov. 2016. Disponível em: http://twixar.me/0qM1. Acesso em: 01 abr. 2019.
}

92 | Revista do Programa de Pós-Graduação em Direito da UFBA, e-issn 2358-4777, v. 30, n. 01, p.78 -105, Jan-Jun 2020 
busca. Este argumento falha ao restringir a possibilidade de aplicação do direito ao esquecimento ao dispositivo mencionado.

Por sua vez, o Ministro Marco Aurélio Bellizze, com base no artigo 11, da mesma Lei, argumentou que o Marco Civil da Internet, ao proteger os registros, os dados pessoais e as comunicações privadas, permite, sim, que seja imputada aos provedores de busca a obrigação de desindexar determinados conteúdos, ao que a Relatora contra-argumentou afirmando que este artigo diz respeito, apenas, à competência legal e judicial brasileira por tráfego de dados, sendo uma cláusula de jurisdição, de modo que não poderia ser utilizada para fundamentar a pretensão da autora.

Dessa feita, observa-se que não houve consenso na Terceira Turma do Superior Tribunal de Justiça acerca da existência ou não de previsão em norma infraconstitucional de um direito à desindexação. No entanto, toda esta discussão poderia ser solucionada por meio da aplicação direta de direitos fundamentais ao caso concreto.

A despeito de em nenhum momento tratarem da eficácia dos direitos fundamentais nas relações entre particulares, os argumentos dos Ministros da Terceira Turma, ao não considerarem reconhecer o direito ao esquecimento no caso em apreço com fundamento direto na Constituição, alinham-se, pelo menos no que atine ao caso em análise, à posição daqueles que defendem a eficácia horizontal dos direitos fundamentais pela via mediata da legislação infraconstitucional, para quem, a aplicação dos direitos fundamentais nas relações privadas demandaria a mediação do órgão estatal, sendo a lei o instrumento mais adequado para a aplicação de um direito fundamental interprivados ${ }^{33}$.

Entretanto, atualmente a doutrina reconhece a força normativa do texto constitucional, o qual passa a conformar todo o sistema jurídico, determinando uma interpretação em conformidade com a Constituição das normas infraconstitucionais ${ }^{34}$. A esse respeito Maria Celina Bodin de Moraes ${ }^{35}$ afirma que mesmo que o legislador ordinário permaneça inerte,

devem o Juiz e o Jurista proceder ao inadiável trabalho de adequação da legislação civil, através de interpretações dotadas de particular 'sensibilidade constitucional' [...] que, em última análise, e sempre, verifiquem o teor e o espírito da Constituição.

Nesse contexto, a dignidade da pessoa humana se apresenta como valor fundante e unificador do sistema, de modo que as relações existenciais predominam sobre as patrimoniais. Desenvolve-se a teoria da aplicabilidade direta dos direitos fundamentais nas relações entre os particulares, sendo desnecessária a obrigatoriedade de existência de lei infraconstitucional para esta aplicação ${ }^{36}$. Assim, conforme ensina Gustavo Tepedino, "O desafio do jurista de hoje

33 EHRHARDT JÚNIOR, Marcos A. A; TORRES, Marcio R. Direitos Fundamentais e as Relações Privadas. Superando a (pseudo) tensão entre aplicabilidade direta e eficácia indireta para além do patrimônio. In: Curitiba: Revista Jurídica, v. $04, \quad$ n. 53,2018 , p. 333. Disponível em: http://revista.unicuritiba.edu.br/index.php/RevJur/ article/view/ 3222/371371738. Acesso em: 01 abr. 2019.

${ }^{34}$ MORAES, Maria Celina Bodin. A constitucionalização do direito civil e seus efeitos sobre a responsabilidade civil. In: Direito, Estado e Sociedade, v. 09, n. 29, p. 233-235, jul./dez. 2006. Disponível em: http://arquivos.integrawebsites.com.br/36192/4c97d92004aee47b8a3eac4f7b9c4e05.pdf. Acesso em: 01 abr. 2019.

35 MORAES, Maria Celina Bodin. A Caminho de um Direito Civil Constitucional. Revista Estado, Direito e Sociedade, Departamento de Ciências Jurídicas da PUC-Rio, v. 1, p. 14, 1991 . Disponível em: http://www.egov.ufsc.br/portal/sites/default/files/anexos/15528-15529-1-PB.pdf. Acesso em: 09 jul. 2019.

${ }^{36}$ MORAES, Maria Celina Bodin. A constitucionalização do direito civil e seus efeitos sobre a responsabilidade civil. In: Direito, Estado e Sociedade, v. 09, n. 29, p. 233-235, jul./dez. 2006. Disponível em:

93 | Revista do Programa de Pós-Graduação em Direito da UFBA, e-issn 2358-4777, v. 30, n. 01, p.78 -105, Jan-Jun 2020 
consiste precisamente na harmonização das fontes normativas, a partir dos valores e princípios constitucionais." ${ }^{37}$.

Ressalte-se que, no Brasil, existe norma constitucional, prevista no artigo 5으, § 10, a qual dispõe que as normas definidoras dos direitos e garantias fundamentais têm aplicação imediata $^{38}$, sendo este, segundo Paulo Lôbo ${ }^{39}$, o principal fundamento pelo qual, no Brasil, deve ser adotada a teoria da aplicabilidade imediata, direta, dos direitos fundamentais nas relações entre os particulares.

$\mathrm{Na}$ decisão analisada, somente o Ministro Moura Ribeiro, o qual reconheceu que nosso ordenamento possui base legal para pretensão da autora, argumentou no sentido de que, ainda que assim não fosse, uma vez que o direito ao esquecimento é um direito fundamental, todos devem respeitá-lo, inclusive os provedores de busca, reconhecendo, pois, tanto a força normativa da Constituição quanto a possibilidade de aplicação direta dos direitos fundamentais na relação entre particulares.

Ressalte-se que o acórdão recorrido aplicou diretamente os direitos fundamentais, reconhecendo o direito ao esquecimento como "consequência do direito à vida privada (privacidade), intimidade e honra, assegurados pela Constituição Federal de 1988", ponderando que no caso havia uma colisão entre direito à intimidade e à privacidade, de um lado, e direito à informação, do outro, devendo prevalecer o "direito à imagem, à personalidade e ao esquecimento, com vista a evitar o exercício da livre circulação de fatos noticiosos por tempo imoderado".

Por oportuno, ainda no que toca à divergência dos votos acerca da existência ou não de dispositivo infraconstitucional que embasasse o direito da autora, cumpre dizer que a Ministra Nancy Andrighi, lamentavelmente, limitou o direito ao esquecimento à previsão do artigo 7으, $\mathrm{X}$, do Marco Civil da Internet, o qual trata apenas do direito ao apagamento, outra forma do direito ao esquecimento.

Já o Ministro Marco Aurélio Bellizze entendeu que o fundamento legal para se imputar aos provedores de busca a obrigação pleiteada pela autora estaria no artigo 11, do Marco Civil da Internet. No entanto, como apontado pela Relatora, este artigo é voltado a definir competência, determinado que todo o tratamento de dados pessoais que ocorrer no Brasil deve estar adequado à legislação brasileira. Dessa forma, os dados pessoais são protegidos não por este dispositivo, mas por outras previsões do nosso ordenamento jurídico, de modo que o mencionado artigo 11 apenas determina que os já previstos "direitos à privacidade, à proteção dos dados pessoais e ao sigilo das comunicações privadas e dos registros" ${ }^{40}$ sejam respeitados.

http://arquivos.integrawebsites.com.br/36192/4c97d92004aee47b8a3eac4f7b9c4e05.pdf. Acesso em: 01 abr. 2019.

${ }^{37}$ TEPEDINO, Gustavo. Normas Constitucionais e Direito Civil. Revista da Faculdade de Direito de Campos, ano IV, n. 4, ano V, n. 5, p. 8, 2003-2004. Disponível em: http://www.uniflu.edu.br/arquivos/Revistas/Revista04e05/Docente/10.pdf. Acesso em: 09 jul. 2019.

38 EHRHARDT JÚNIOR, Marcos A. A; TORRES, Marcio R. Direitos Fundamentais e as Relações Privadas. Superando a (pseudo) tensão entre aplicabilidade direta e eficácia indireta para além do patrimônio. In: Curitiba: Revista Jurídica, v. 04 , n. 53, 2018, p. 335. Disponível em: http://revista.unicuritiba.edu.br/index.php/RevJur/article/view/ 3222/371371738. Acesso em: 01 abr. 2019.

39 LÔBO, Paulo. Metodologia do direito civil constitucional. In: EHRHARDT JÚNIOR, Marcos. et al. Direito civil constitucional: a ressignificação da função dos institutos fundamentais do direito civil contemporâneo e suas consequências. Florianópolis: Conceito, 2014, p. 23-24.

${ }^{40}$ BRASIL. Lei no 12.965, de 23 de abril de 2014. Estabelece princípios, garantias, direitos e deveres para o uso da Internet no Brasil. Disponível em: http://www.planalto.gov.br/ccivil_03/_ato20112014/2014/lei/l12965.htm. Acesso em: 01 abr. 2019.

94 | Revista do Programa de Pós-Graduação em Direito da UFBA, e-issn 2358-4777, v. 30, n. 01, p.78 -105, Jan-Jun 2020 
$\mathrm{Na}$ verdade, o fundamento do direito à desindexação no Marco Civil da Internet estaria no artigo 19, caput, que ao dispor que o provedor de aplicações de internet - e aqui estão incluídos os provedores de busca -, somente poderá ser responsabilizado civilmente por danos decorrentes de conteúdo gerado por terceiros se, após ordem judicial específica, não tomar as providências para tornar indisponível o conteúdo apontado como infringente, além de assumir a possibilidade de responsabilização dos provedores de aplicações por conteúdo gerado por terceiros, permite a interpretação de que o indivíduo pode demandar os provedores de pesquisa para que suprimam determinado conteúdo de seus resultados, o que nada mais é do que o reconhecimento do direito à desindexação.

A esse respeito, vale lembrar o caso González vs. Google Spain, o qual tratou de uma ação movida pelo advogado Mario Costeja González, por meio da qual intentava que o Google removesse de seus resultados uma publicação referente a leilão de imóveis de sua propriedade em razão de ação por dívidas com a Seguridade Social. As notícias foram publicadas pelo jornal La Vanguardia e, embora o autor já tivesse pago suas dívidas, a notícia continuava a aparecer no buscador $^{41}$.

Nesse caso, o Tribunal de Justiça da União Europeia adotou duas posições distintas em relação ao jornal e ao Google. Quanto ao jornal, o TJUE entendeu que este não deveria ser obrigado a apagar a página na qual constava a informação do leilão, visto que, embora a notícia fosse antiga, ela tinha justificação legal. No entanto, quanto ao Google, o Tribunal entendeu que, além de um motor de busca, a empresa realiza o tratamento de informações, tornando-se responsável pelos dados pessoais incluídos em sites indexados em seu serviço de busca, de modo que, embora a informação não seja considerada ilícita, caso o indivíduo se sinta prejudicado, a indexação não poderá ser feita ${ }^{42}$.

Outro ponto de divergência diz respeito à necessidade de indicação das URLs no pedido de desindexação.

Nesse ponto, cumpre dizer que sob a ótica da hermenêutica civil-constitucional, o exercício de um direito fundamental não pode ser obstado por lei infraconstitucional. Em que pese estes direitos não serem absolutos e, portanto, poderem sofrer restrições, as limitações devem ocorrer por meio de outras normas constitucionais, como no caso de colisão entre dois direitos fundamentais ou por meio de leis às quais a Constituição atribuiu tal competência.

Assim, de fato o artigo $19, \S 1$ o, do Marco Civil da Internet, exige que a ordem judicial que determine a desindexação de conteúdo contenha identificação clara e específica do conteúdo, permitindo a localização inequívoca do material. No entanto, o intérprete deverá observar, em cada caso, se esta exigência inviabiliza o exercício do direito à privacidade e do direito ao esquecimento. Outrossim, a ausência de indicação da URL não deve servir de justificativa para negar direito, haja vista que, processualmente, tal ausência poderia ser suprida, máxime a partir do atual Código de Processo Civil, que consagrou, em seus artigos 4ㅇ e 6으, o princípio da primazia da resolução de mérito, estabelecendo que os sujeitos do processo devem cooperar entre si para que as partes obtenham, em prazo razoável, a solução integral do mérito, incluída a atividade satisfativa.

\footnotetext{
${ }^{41}$ O TRIBUBAL da UE endossa o 'direito ao esquecimento' na Internet. El Pais Brasil, 13 maio 2014. Disponível em: Disponível em: https://brasil.elpais.com/brasil/2014/05/12/sociedad/_1399921965_465484.html. Acesso em: 09 jul. 2019.

42 AGÊNCIA EFE. Espanhol vence ação contra Google por 'direito ao esquecimento' na internet. Época Negócios, 13 maio 2014. Disponível em: https://epocanegocios.globo.com/Informacao/Visao/noticia/2014/05/ espanhol-vence-acao-contra-google-por-direito-ao-esquecimento-na-internet.html. Acesso em: 09 jul. 2019.
}

95 | Revista do Programa de Pós-Graduação em Direito da UFBA, e-issn 2358-4777, v. 30, n. 01, p.78 -105, Jan-Jun 2020 
Por exemplo, se o fato a ser esquecido foi veiculado por milhares de páginas, torna-se impossível ao indivíduo indicar todas as URLS, de modo que poderia ser feito e julgado procedente pedido genérico de desindexação, como ocorreu no caso analisado.

Nesse sentido, o Ministro Moura Ribeiro, argumentou que a ampla proteção dos direitos fundamentais "é mais do que uma meta constitucional, é também um norte hermenêutico. As normas, quer constitucionais, quer infraconstitucionais, devem ser interpretadas no sentido que Ihes dê a maior amplitude."

Insta dizer que o STJ, até então, negava todas as pretensões genéricas nesse sentido, como no julgamento do REsp 1406448/RJ, pela Terceira Turma do STJ, em 15/10/2013. Já nos tribunais inferiores é mais comum encontrar decisões que não indicam URL, como no Acórdão recorrido no caso que ora se analisa, bem como no Acórdão da Apelação Cível nํ113249475.2015.8.26.0100

Ressalte-se que decisões nesse sentido poderiam minorar o efeito Streisand, que é o nome dado ao fenômeno que muitas vezes acontece ao se tentar remover ou censurar algum conteúdo da internet: a informação ganha ainda mais visibilidade ${ }^{44}$.

A ocorrência desse fenômeno, inclusive, foi um dos argumentos utilizados nos votos vencidos, os quais concluíram que a medida pleiteada não era útil nem necessária, uma vez que, à medida que várias notícias sobre o julgamento seriam noticiadas e o fato que se pretendia ver esquecido seria cada vez mais lembrado. E realmente isso ocorreu, o que é perceptível quando é realizada uma pesquisa pelo nome da autora da ação no Google, sem associação a nenhum outro termo de busca, a qual apresenta como principais resultados notícias relacionadas à fraude mencionada na ação ou ao julgamento do REsp aqui analisado.

Destaque-se, ainda, que no mesmo resultado de busca o Google apresenta a seguinte mensagem: "Atendendo a uma solicitação oficial enviada ao Google, removemos 11 resultado(s) de pesquisa desta página", ou seja, aparentemente, apenas uma pequena parte do pleito autoral foi atendida, pois os novos conteúdos podem ter sido incluídos após o julgado, entretanto, a condenação do Google ocorreu no sentido de que fosse implementado um filtro que permitisse que, mesmo após o julgamento, os resultados das pesquisas pelo nome da autora não fizessem referência às notícias de fraude.

Ainda no que atine ao pedido genérico, cumpre mencionar que os recorrentes alegaram, e sempre alegam em casos semelhantes, a impossibilidade técnica de se atender a ordens judiciais de desindexação que não indiquem as páginas específicas que serão desindexadas. No caso em apreço, a Microsoft afirmou que não há tecnologia capaz de criar um mecanismo que fosse hábil a verificar quando o resultado da busca realmente fizesse referencia à autora e não a homônimos, bem como de fazer juízo de valor para filtrar aqueles que dissessem respeito ao concurso da magistratura já mencionado.

Acerca disso, os provedores de busca se furtam a desenvolver algoritmos aptos a cumprirem esse tipo de determinação judicial, pois comungam a ideia de que não se pode "sair da internet". É possível que não exista tecnologia hoje para implantar esse tipo de filtro, mas por falta de interesse dos provedores de pesquisa e não por ser tecnicamente impossível.

\footnotetext{
${ }^{43}$ SÃO PAULO. Tribunal de Justiça do Estado de São Paulo. Apelação Cível no 1132494-75.2015.8.26.0100.

3a Câmara de Direito Privado. Apelante: Ney de Souza Pereira. Apelado: Google Brasil Internet Ltda. Relator: Beretta da Silveira. São Paulo, 14 jun. 2017. Disponível em: http://twixar.me/brM1. Acesso em: 01 abr. 2019.

${ }^{44} \mathrm{ACIOLI}$, Bruno L. O Direito ao Esquecimento e o Livre Fluxo de Informações na Internet: reconhecimento, aplicação e efetividade deste direito no Brasil. 2018, p. 137. Dissertação (Mestrado em Direito) - Faculdade de Direito de Alagoas, Universidade Federal de Alagoas, Maceió. Disponível em: http://twixar.me/YkM1. Acesso em: 01 abr. 2019.
}

96 | Revista do Programa de Pós-Graduação em Direito da UFBA, e-issn 2358-4777, v. 30, n. 01, p.78 -105, Jan-Jun 2020 
Entretanto, é oportuno relembrar casos envolvendo empresas de tecnologia com atuação na China, a exemplo de Baidu e Google.

Em relação a Baidu, pode ser mencionada notícia que fez referência a uma retirada de um termo cuja censura foi determinada pelo governo chinês ${ }^{45}$. Ora, o fato deixa claro que existe tecnologia capaz de filtrar conteúdos na internet, mais ainda, conteúdo especificamente relacionado a um fato ou pessoa.

O caso chinês é uma realidade diferenciada, dado o elevado grau de controle por parte do governo, mas toda empresa que deseje se instalar no país deve se adequar às normas impostas pelo governo chinês. Esse foi o caso, por exemplo, do Google, quando instalado na China, o qual chegou a anunciar que "[...] não censuraria mais os resultados de buscas em seu site na China, e passou a encaminhar os usuários do site chinês ao seu site em Hong Kong" ${ }^{46}$

Nos casos citados é possível perceber que existe tecnologia suficientemente avançada para restringir o acesso dos usuários, de maneira geral, a conteúdos específicos, portanto, podese concluir que também existe tecnologia capaz de filtrar as informações acerca de uma pessoa ou fato. Assim, o pedido da autora poderia, sim, ser efetivado, ainda que houvesse falhas no filtro.

Já no que diz respeito ao argumento da Ministra Relatora de que decisões genéricas, que obrigassem os provedores de busca a desindexar links de páginas que relacionassem a autora à suposta fraude, sem especificá-las, seria transformar estes provedores em verdadeiros censores digitais, inclusive podendo censurar páginas do site do próprio STJ que noticiassem sobre o caso, importa dizer que não é censura os mecanismos de busca filtrarem os resultados quando o único parâmetro de pesquisa for o nome da autora.

Cumpre, aqui, fazer duas observações: quando a autora ingressou com a ação, o Marco Civil ainda não estava em vigor, razão pela qual a exigência da URL em legislação não existia à época. Ademais, os buscadores de pesquisa poderiam, em cooperação processual, indicar uma lista de links para que a autora manifestasse quais deles ela gostaria de ver desindexados.

Isso porque nenhuma página será retirada da internet, de modo que as pessoas poderão ser informadas a respeito do caso ao acessarem o site na qual se encontre a publicação original. Assim, ao acessarem o site do STJ, as pessoas terão acesso às eventuais notícias sobre o caso. Ademais, outros termos de pesquisa, para os quais esses resultados realmente fossem relevantes, não sofreriam qualquer filtro ${ }^{47}$.

Por exemplo, ao combinarem o nome da autora com o termo de pesquisa "fraude a concurso" 48 , as pessoas teriam acesso às notícias sobre o suposto ilícito que envolveu

\footnotetext{
${ }^{45}$ BARREDO, Alex. Liberdade de Expressão - Baidu desafia China ao eliminar parte da censura. 09 maio 2016. Disponível em: https://hipertextual.com/2016/05/baidu-censura-china. Acesso em: 09 jul. 2019.

${ }^{46}$ BAIDU e China são processadas nos EUA por censura. 05 dez. 2013. Exame. Disponível em: https://exame. abril.com.br/tecnologia/baidu-e-china-sao-processadas-nos-eua-por-censura-a-internet/. Acesso em: 09 jul. 2019.

47 Uma rápida pesquisa realizada no dia 09 de julho de 2019, no buscador Google Brasil, utilizando como indicador apenas o nome completo da requerente, dentre as primeiras dez páginas apresentadas como resultado, apenas 02 fazem referência direta ao caso de fraude em concurso no qual o nome da autora foi envolvido. Os demais resultados se referem a páginas de informações profissionais (03) e a informações sobre a ação movida pela autora e/ou direito ao esquecimento (05). No mesmo resultado de pesquisa é informado, ainda que, "Atendendo a uma solicitação oficial enviada ao Google, removemos 7 resultado(s) de pesquisa desta página".

48 Uma busca, realizada no dia 09 de julho de 2019, utilizando-se o Google Brasil, combinando-se como indicadores o nome completo da autora e "fraude a concurso", resultou, dentre as 10 primeiras páginas apresentadas em 04 páginas com referência direta ao caso de suspeita de fraude em concurso no qual a autora foi envolvida, sendo os demais resultados referentes a currículo da autora (01) e notícias sobre direito ao 97 | Revista do Programa de Pós-Graduação em Direito da UFBA, e-issn 2358-4777, v. 30, n. 01, p.78 -105, Jan-Jun 2020
} 
o nome da requerente. Também, ao pesquisar sobre direito ao esquecimento ${ }^{49}$, o usuário teria acesso às notícias referentes ao julgamento do caso.

Logo, a medida pleiteada apenas deixaria de trazer essas notícias como resultados da pesquisa quando o único parâmetro de busca fosse o nome da autora, haja vista que, para quem realizasse esse tipo de pesquisa, as informações sobre a suposta fraude estão desatualizadas e não são de interesse público, não devendo constar dos resultados de quem pesquisa provido apenas de curiosidade.

No entanto, cumpre trazer à discussão entendimentos contrários, como o de Daniel Sarmento, para quem a transferência de responsabilidade a instituições privadas, como os provedores de busca, de ponderar o direito à privacidade em face do direito à informação estimula a censura privada. Para ele, no Brasil é inaplicável o direito ao esquecimento tal qual ocorre na Europa - que permite que cada usuário solicite diretamente aos provedores de busca a desindexação de determinado conteúdo -, pois os direitos de liberdade de expressão teriam posição preferencial no ordenamento brasileiro. A esse respeito, afirma:

Considerando a responsabilidade civil dos provedores de buscas, esta solução tende a gerar o resfriamento dos debates na Internet, pois estimula o exercício da censura privada, para evitar possíveis condenações à reparação de danos. O modelo desenhado pelo Tribunal de Justiça da União Europeia tem, em minha opinião, impactos muito severos e desproporcionais sobre o direito de acesso à informação e sobre as liberdades comunicativas, não sendo legítima a sua adoção no Brasil, considerando a posição preferencial desfrutada por tais direitos em nossa ordem constitucional ${ }^{50}$.

Por oportuno, importa dizer que, à época do julgamento, ainda não havia uma lei geral que tratasse sobre a proteção de dados pessoais no Brasil, como bem destacado pela Ministra Relatora. Contudo, em agosto do ano passado foi sancionada a Lei 13.709/2018 - Lei Geral de Proteção de Dados Pessoais.

Essa Lei, ainda em vacatio legis e que foi inspirada no Regulamento Geral de Proteção de Dados da União Europeia, traz dispositivos que viabilizarão o direito ao esquecimento.

Nesse sentido, o artigo 18, IV, da Lei 13.709/2018, prevê que o titular dos dados pessoais tem o direito de obter do controlador, mediante requisição, a "anonimização, bloqueio ou

esquecimento ou ao processo judicial movido pela autora em relação ao direito ao esquecimento (05). Ainda, ao final da página, foi exibida a mensagem: "Atendendo a uma solicitação oficial enviada ao Google, removemos 11 resultado(s) de pesquisa desta página". Essa observação demonstra que o Google não implementou o filtro nos termos da decisão, uma vez que, quando o nome da autora fosse combinada com a expressão "fraude a concurso", nenhum resultado deveria ser omitido. Assim, provavelmente o Google apenas desindexou de um modo geral os resultados que, à época da decisão, eram apresentados ao se buscar o nome da autora no provedor de pesquisa.

${ }^{49}$ Busca realizada no Google Brasil no dia 09 de julho de 2019, após o julgamento ora analisado, combinando o nome completo da autora com "direito ao esquecimento", entre as dez primeiras páginas apresentadas, resultou em referências à ação movida pela autora sobre seu direito ao esquecimento (09) e apenas 01 página apresentando o currículo da autora. No mais, foi mostrada a seguinte mensagem ao final da página de busca: "Atendendo a uma solicitação oficial enviada ao Google, removemos 8 resultado(s) de pesquisa desta página".

50 SARMENTO, Daniel. Liberdades comunicativas e "Direito ao Esquecimento" na ordem constitucional brasileira. Revista Brasileira de Direito Civil, v. 7, p. 208, jan./mar. 2016. Disponível em: https://rbdcivil.ibdcivil.org.br/rbdc/article/view/76. Acesso em: 09 jul. 2019.

98 | Revista do Programa de Pós-Graduação em Direito da UFBA, e-issn 2358-4777, v. 30, n. 01, p.78 -105, Jan-Jun 2020 
eliminação de dados desnecessários, excessivos ou tratados em desconformidade com o disposto nesta Lei".

Também o artigo 15, I, da Lei 13.709/2018 dispõe que ocorrerá o término do tratamento de dados pessoais quando verificado que a finalidade foi alcançada ou de que os dados deixaram de ser necessários ou pertinentes ao alcance da finalidade específica almejada.

Nessa senda, se uma informação desatualizada está causando dano à pessoa a quem a informação diz respeito, bem como não há interesse público que tal informação continue sendo veiculada, esse dado, além de ter cumprido a sua finalidade, qual seja, a de informar, também é desnecessário e excessivo, razão pela qual o titular do dado pessoal poderá requerer a eliminação da informação, inclusive aos provedores de pesquisa, como já acontece na Europa, haja vista que estes também realizam tratamento de dados e, portanto, serão alcançados pela Lei 13.709/2018.

Na Europa, o direito à desindexação no caso Google Spain vs. Mário Costeja González foi reconhecido com base no artigo 12, da Diretiva 95/46/CE ${ }^{51}$. O Regulamento Geral de Proteção de Dados Pessoais manteve o direito à desindexação, ao prever, em seu artigo 17.․, que

1. O titular tem o direito de obter do responsável pelo tratamento o apagamento dos seus dados pessoais, sem demora injustificada, e este tem a obrigação de apagar os dados pessoais, sem demora injustificada, quando se aplique um dos seguintes motivos:

a) Os dados pessoais deixaram de ser necessários para a finalidade que motivou a sua recolha ou tratamento;

b) $O$ titular retira o consentimento em que se baseia o tratamento dos dados nos termos do artigo 6.․, n.o 1, alínea a), ou do artigo 9., n.ㅇ 2, alínea a) e se não existir outro fundamento jurídico para o referido tratamento;

c) O titular opõe-se ao tratamento nos termos do artigo $21 . \stackrel{\circ}{\mathrm{n}} \mathrm{n} . \mathrm{0} 1$, e não existem interesses legítimos prevalecentes que justifiquem 0 tratamento, ou o titular opõe-se ao tratamento nos termos do artigo 21.ㅇ, n.ㅇ 2;

d) Os dados pessoais foram tratados ilicitamente. [...].

Desse modo, a LGPD traz uma previsão semelhante à do RGPD no que diz respeito ao apagamento dos dados. Por conseguinte, se na Europa é possível solicitar a eliminação de informação de provedores de busca com base neste Regulamento, a mesma solução também pode ser adotada no Brasil ${ }^{52}$.

Saliente-se, ainda, que o Google, para se adequar ao RGPD, implementou um formulário online $^{53}$ para receber pedidos de desindexação de conteúdo, bem como tem cumprido as decisões judiciais que determinam a desindexação dos resultados do buscador perante o

\footnotetext{
51 “Os Estados-membros garantirão às pessoas em causa o direito de obterem do responsável pelo tratamento: [...]. b) Consoante o caso, a rectificação, o apagamento ou o bloqueio dos dados cujo tratamento não cumpra o disposto na presente directiva, nomeadamente devido ao carácter incompleto ou inexacto desses dados;"

52 Importa ressaltar que a Lei Geral de Proteção de Dados Pessoais não se aplica ao tratamento de dados pessoais realizado para fins exclusivamente jornalísticos, conforme artigo 4으, II, a, da Lei 13.709/2018.

${ }^{53} \mathrm{O}$ formulário pode ser encontrado em: https://www.google.com/webmasters/tools/legal-removalrequest?complaint_type=rtbf\&visit_id=637050051802302488-1746832855\&hl=pt-PT\&rd=1.
}

99 | Revista do Programa de Pós-Graduação em Direito da UFBA, e-issn 2358-4777, v. 30, n. 01, p.78 -105, Jan-Jun 2020 
território de origem do país que proferiu a decisão ${ }^{54}$. Espera-se que o Google adote a mesma medida para se adequar à legislação brasileira.

Isso posto, quando a Lei Geral de Proteção de Dados Pessoais entrar em vigor, as decisões do STJ sobre casos parecidos deverão conceder o direito à desindexação mais facilmente, já que haverá uma base legal mais definida.

\section{Conclusão}

Como visto, a tecnologia, principalmente a partir do advento da internet, possibilitou a transferência e o acesso de dados em segundos, permitindo que boa parte do conhecimento sobre tudo e sobre todos esteja a apenas um clique.

No entanto, quando uma pesquisa é feita em um site de busca, um algoritmo fará uma listagem de resultados que mais correspondem com os parâmetros de busca cuja ordem é influenciada por centenas de resultados e nenhum deles diz respeito à relevância da informação para o interesse público.

Aqui, importa frisar que interesse público é diferente de interesse do público. Embora muitas pessoas tenham interesse em saber sobre a vida de alguém, na maior parte das vezes, esse interesse não passa de mera curiosidade, não sendo possível afirmar que tal conhecimento é de interesse público. Isso porque não se trata de qualquer informação que importe ao indivíduo enquanto cidadão, num contexto de uma sociedade democrática. Não atine, por exemplo, ao uso do dinheiro público, decisões e alianças políticas, ocorrência e julgamento de crimes, fatos e acontecimentos históricos, isto é, não é uma informação que interesse à coletividade.

Os mecanismos de busca, ainda, consideram a quantidade de acessos que uma página no momento de ordenar os resultados da pesquisa. Isso significa que, quanto mais acessos uma página tiver, mais no topo do ranking ela estará. O que, por sua vez, acaba atraindo mais cliques para a página. Toda essa dinâmica, não raramente, cria situações em que, quando uma pesquisa sobre alguém é realizada na internet, os primeiros resultados mostrados são sobre fatos que, ainda que verdadeiros, causam prejuízos aos direitos da personalidade da pessoa envolvida, sem que haja qualquer direito à informação que justifique tamanha exposição.

Para tutelar a pessoa diante desse tipo de situação, alguns ordenamentos jurídicos têm reconhecido o direito ao esquecimento, o qual, como visto, pode ser entendido como o direito de o indivíduo não ser obrigado a ter recordado certos fatos de sua vida. Esse direito abrange algumas categorias, sendo uma delas o direito à desindexação, isto é, o direito à exclusão dos resultados de buscas dos provedores de pesquisa de hyperlinks que direcionam os usuários a páginas da internet que apresentem conteúdos irrelevantes ou desatualizados sobre o indivíduo.

Como demonstrado, a doutrina não é uníssona no que diz respeito ao reconhecimento do direito ao esquecimento pelo direito pátrio. De um lado, estão aqueles que entendem que a tutela da dignidade da pessoa humana inclui tal direito. Do outro, estão aqueles que defendem que a atual Carta Magna não permite esse reconhecimento, haja vista que a Constituição teria colocado a liberdade de informação em posição preferencial quando em conflito com outros direitos.

No que diz respeito ao direito à desindexação, como demonstrado, boa parte dos precedentes judiciais apontava que não havia fundamento legal para o reconhecimento desse

54 OLIVEIRA, Caio César de Oliveira. Advogado Geral da EU sugere limitação territorial para 'Direito ao esquecimento'. Jota - Opinião \& Análise, 18 jan. 2019. Disponível em: http://twixar.me/LrM1. Acesso em: 09 jul. 2019.

100 | Revista do Programa de Pós-Graduação em Direito da UFBA, e-issn 2358-4777, v. 30, n. 01, p.78 -105, Jan-Jun 2020 
direito, exceto em casos específicos, para os quais era exigida, ainda, a indicação precisa das URL. Entretanto, se o STJ tivesse utilizado a metodologia civil-constitucional na resolução desses casos, poderia ter decidido diferente, haja vista que o exercício de um direito fundamental não pode ser obstado por lei infraconstitucional.

Nesse particular, o posicionamento aqui defendido é a de que existe no ordenamento jurídico brasileiro uma cláusula geral de tutela da pessoa humana que permite o reconhecimento de direitos fundamentais implícitos, aí se incluindo o direito ao esquecimento.

Dessa forma, havendo conflito entre o direito ao esquecimento e o direito à informação, deve ser feita a ponderação entre esses direitos de acordo com as circunstâncias do caso concreto. $\mathrm{O}$ que não se pode é permitir que a pessoa fique completamente desprotegida diante de situações nas quais informações que, mesmo que em determinado momento tenham sido lícítas, agora servem muito mais a prejudicar do que a informar, principalmente na internet, local onde o alcance da informação pode ser mundial e eterno.

No julgamento do REsp no 1.660.168-RJ, a decisão analisada se afastou dos precedentes do STJ para reconhecer o direito à desindexação de conteúdo, inclusive de maneira genérica, já que não houve indicação das URLs a serem desindexadas.

Nesse sentido, reafirmou o reconhecimento do direito ao esquecimento como um direito fundamental decorrente da tutela da pessoa humana e do direito à privacidade enquanto direito à autodeterminação informativa. Ressalte-se, contudo, que a maior parte da divergência esteve cingida à argumentação acerca da existência ou não de fundamento legal para a desindexação, quando esse fundamento poderia ser extraído da própria Constituição Federal.

A decisão representou um avanço para a compreensão do direito ao esquecimento, uma vez que entendeu que os provedores de busca podem ser responsabilizados, bem como que a indicação da URL nem sempre é necessária, dois posicionamentos inéditos no STJ até então. Por outro lado, para os mais cautelosos, esta decisão representa verdadeiro estímulo à censura privada e afronta à liberdade de expressão.

No entanto, não se trata de censura, já que as páginas não serão excluídas dos provedores em que estejam, assim como outros termos de pesquisa, inclusive ao combinar o nome da autora com "fraude a concurso" o usuário terá acesso às notícias. Assim, o que ocorreu, na verdade, foi permitir a adequada coexistência do direito à informação com o direito da autora de ser esquecida e determinar como pretende construir sua esfera particular. Dessa feita, ponderando-se os bens jurídicos envolvidos, a solução adotada foi a que permitiu que ambos os direitos tivessem a máxima efetividade possível de acordo com as circunstancias do caso concreto.

Nesse ponto, o grande problema é de ordem prática, haja vista que os provedores de busca alegaram a impossibilidade técnica de implantar filtros que determinem qual conteúdo deve ser desindexado e, em que pese a sucumbência, não buscaram solucionar o problema, de modo que, quando são realizadas pesquisas com o nome da autora em qualquer um destes sites de busca, os principais resultados são páginas sobre a suposta fraude que envolveu o seu nome, as quais, frise-se, aumentaram consideravelmente em razão deste julgamento.

Dessa feita, a autora viu seu direito ao esquecimento ser reconhecido judicialmente, no entanto, esse direito não foi efetivado. Em não havendo mudanças quanto a isso no futuro, o que se verá é que o direito à desindexação deixará de ser pleiteado, haja que vista que lutar para assegurá-lo pode, paradoxalmente, encerrar qualquer possibilidade de esquecimento na sociedade da informação.

Nesse sentido, nem a Lei Geral de Proteção de Dados Pessoais que, ao entrar em vigor, definirá bases legais mais claras para a aplicação do direito à desindexação, será capaz de 
apresentar soluções viáveis a esta questão, persistindo o desafio de continuar pesquisando alternativas para o enfretamento da questão.

\section{Referências}

ACIOLI, Bruno L. O Direito ao Esquecimento e o Livre Fluxo de Informações na Internet:

reconhecimento, aplicação e efetividade deste direito no Brasil. 2018. Dissertação (Mestrado em Direito) - Faculdade de Direito de Alagoas, Universidade Federal de Alagoas, Maceió. Disponível em: http://twixar.me/YkM1. Acesso em: 22 mar. 2019.

AGÊNCIA EFE. Espanhol vence ação contra Google por 'direito ao esquecimento' na internet. Época Negócios, 13 maio 2014. Disponível em: https://epocanegocios.globo.

com/Informacao/Visao/noticia/2014/05/espanhol-vence-acao-contra-google-por-direito-aoesquecimento-na-internet.html. Acesso em: 09 jul. 2019.

BAIDU e China são processadas nos EUA por censura. 05 dez. 2013. Exame. Disponível em: https://exame.abril.com.br/tecnologia/baidu-e-china-sao-processadas-nos-eua-por-censura-ainternet/. Acesso em: 09 jul. 2019.

BARREDO, Alex. Liberdade de Expressão - Baidu desafia China ao eliminar parte da censura. 09 maio 2016. Disponível em: https://hipertextual.com/2016/05/baidu-censura-china. Acesso em: 09 jul. 2019.

BRANCO, Sérgio. Memória e Esquecimento na Internet. Porto Alegre: Arquipélago Editorial, 2017.

BRASIL. CJF. VI Jornada de Direito Civil. Enunciado 531. 2013. Disponível em: https://www.cjf.jus.br/enunciados/enunciado/142. Acesso em: 22 mar. 2019.

BRASIL. Lei no 10.406, de 10 de janeiro de 2002. Institui o Código Civil. Disponível em: http://www.planalto.gov.br/ccivil_03/leis/2002/l10406.htm. Acesso em: 09 jul. 2019.

BRASIL. Lei no 12.965, de 23 de abril de 2014. Estabelece princípios, garantias, direitos e deveres para o uso da Internet no Brasil. Disponível em: http://www.planalto.gov.br/ccivil_03/_ato20112014/2014/lei/l12965.htm. Acesso em: 22 mar. 2019.

BRASIL. Lei no 13.709, de 14 de agosto de 2018. Lei Geral de Proteção de Dados Pessoais (LGPD). Disponível em: http://www.planalto.gov.br/ccivil_03/_ato2015-

2018/2018/lei/L13709.htm\#art65. Acesso em: 09 jul. 2019.

BRASIL. Superior Tribunal de Justiça (3. Turma). AgInt no REsp 1593873/SP. Recorrente: Google Brasil Internet Ltda. Recorrido: S. M. S. Relatora: Min. Nancy Andrighi, 19 mar. 2018. Disponível em: http://twixar.me/0qM1. Acesso em: 09 jul. 2019.

BRASIL. Superior Tribunal de Justiça (3. Turma). REsp 1316921/RJ. Recorrente: Google Brasil Internet Ltda. Recorrido: Maria da Graça Xuxa Meneghel. Relatora: Min. Nancy Andrighi, 26 jun. 2012. Disponível em: https://www.internetlab.org.br/wp-content/uploads/2017/02/STJ-REsp1316921.pdf. Acesso em: 09 jul. 2019.

102 | Revista do Programa de Pós-Graduação em Direito da UFBA, e-issn 2358-4777, v. 30, n. 01, p.78 -105, Jan-Jun 2020 
BRASIL. Superior Tribunal de Justiça (3. Turma). REsp 1679465/SP. Recorrente: Google Brasil Internet Ltda. Recorrido: Ministério Público do Estado de São Paulo. Relatora: Min. Nancy Andrighi, 19 mar. 2018. Disponível em: https://ww2.stj.jus.br/

processo/revista/documento/mediado/?componente=ITA\&sequencial=1685789\&num_registro= 201602042165\&data=20180319\&formato=PDF. Acesso em: 09 jul. 2019.

BRASIL. Superior Tribunal de Justiça. Recurso Especial no 1.660.168 - RJ (2014/0291777-1). Recorrente: Yahoo! Do Brasil Internet Ltda. Recorrente: Google Brasil Internet Ltda. Recorrido: DPN. Interessado: Microsoft Informática Ltda. Relatora: Ministra Nancy Andrighi. Data de Julgamento: 08 maio 2018. Disponível em: https://ww2.stj.jus.br/processo/revista/documento/mediado/?componente=ITA\&sequencial=16 28798\&num_registro=201402917771\&data=20180605\&formato=PDF. Acesso em: 22 mar. 2019.

BUCAR, Daniel. Controle temporal de dados: o direito ao esquecimento. Civilista.com, ano 2, n. 3, 2013. Disponível em: http://civilistica.com/wp-content/uploads/2015/02/ Bucarcivilistica.com. a.2.n.3.2013. Acesso em: 09 jul. 2019.

DE TERWANGNE, Cecile. The Right to be Gorgotten and the Informational Autonomy in the Digital Environment. European Comission, Luxemburgo: Escritório de Publicações da União Européia, 2013. Disponível em: https://ec.europa.eu/jrc/en/ publication/right-be-forgotten-andinformational-autonomy-digital-environment. Acesso em: 09 jul. 2019.

EHRHARDT JÚNIOR, Marcos A. A; ACIOLI, Bruno L. Uma agenda para o direito ao esquecimento no Brasil. In: Revista Brasileira de Políticas Públicas - Direito e mundo digital, v. 7, n. 3, dez. 2017, p. 399. Disponível em: https://www.publicacoes academicas.uniceub.br/RBPP/article/view/4867/3671. Acesso em: 28 mar. 2019.

EHRHARDT JÚNIOR, Marcos A. A; TORRES, Marcio R. Direitos Fundamentais e as Relações Privadas. Superando a (pseudo) tensão entre aplicabilidade direta e eficácia indireta para além do patrimônio. In: Curitiba: Revista Jurídica, v. 04, n. 53, 2018, p. 343. Disponível em: http://revista.unicuritiba.edu.br/index.php/RevJur/article/view/3222/371371738. Acesso em: 28 mar. 2019.

EHRHARDT JÚNIOR, Marcos. et al. Direito civil constitucional: a ressignificação da função dos institutos fundamentais do direito civil contemporâneo e suas consequências. Florianópolis: Conceito, 2014. Disponível em: http://twixar.me/XqM1. Acesso em: 09 jul. 2019.

MORAES, Maria Celina Bodin. A Caminho de um Direito Civil Constitucional. Revista Estado, Direito e Sociedade, Departamento de Ciências Jurídicas da PUC-Rio, v. 1, 1991. Disponível em: http://www.egov.ufsc.br/portal/sites/default/files/anexos/15528-15529-1-PB.pdf. Acesso em: 09 jul. 2019.

MORAES, Maria Celina Bodin. A constitucionalização do direito civil e seus efeitos sobre a responsabilidade civil. In: Direito, Estado e Sociedade, v. 09, n. 29, p. 233-258, jul./dez. 2006. Disponível em: http://arquivos.integrawebsites.com.br/36192/ 4c97d92004aee47b8a3eac4f7b9c4e05.pdf. Acesso em: 01 abr. 2019. 
MORAES, Maria Celina Bodin de. Danos à Pessoa Humana: uma Leitura Civil-Constitucional dos Danos Morais. Rio de Janeiro: Renovar, 2003.

OLIVEIRA, Caio César de Oliveira. Advogado Geral da EU sugere limitação territorial para 'Direito ao esquecimento'. Jota - Opinião \& Análise, 18 jan. 2019. Disponível em:

http://twixar.me/LrM1. Acesso em: 09 jul. 2019.

O TRIBUBAL da UE endossa o 'direito ao esquecimento' na Internet. El Pais Brasil, 13 maio 2014. Disponível em: https://brasil.elpais.com/brasil/2014/05/12/sociedad/

1399921965_465484.html. Acesso em: 09 jul. 2019.

PEIXOTO, Erick L. C; EHRHARDT JÚNIOR, Marcos. Breves notas sobre a ressignificação da privacidade. In: Belo Horizonte: Revista Brasileira de Direito Civil, v. 16, abr./jun. 2018, p. 42. Disponível em: https://rbdcivil.ibdcivil.org.br/rbdc/article/view/230/212. Acesso em: 22 mar. 2019.

SÃO PAULO. Tribunal de Justiça do Estado de São Paulo. Apelação Cível no 113249475.2015.8.26.0100. 3a Câmara de Direito Privado. Apelante: Ney de Souza Pereira. Apelado: Google Brasil Internet Ltda. Relator: Beretta da Silveira. São Paulo, 14 jun. 2017. Disponível em: http://twixar.me/brM1. Acesso em: 22 mar. 2019.

SARLET, Ingo Wolfgang. Proteção da Personalidade no Ambiente Digital: uma análise a luz do caso do assim chamado Direito ao Esquecimento no Brasil. Espaço Jurídico Journal of Law (EJIL), Joaçaba, v. 19, n. 2, maio/ago. 2018. Disponível em:

https://portalperiodicos.unoesc.edu.br/espacojuridico/article/view/17557. Acesso em: 09 jul. 2019.

SARMENTO, Daniel. Liberdades comunicativas e "Direito ao Esquecimento" na ordem constitucional brasileira. Revista Brasileira de Direito Civil, v. 7, jan./mar. 2016. Disponível em: https://rbdcivil.ibdcivil.org.br/rbdc/article/view/76. Acesso em: 09 jul. 2019.

SCHREIBER, Anderson. As três correntes do direito ao esquecimento. Jota - Opinião \& Análise, 18 jun. 2017. Disponível em: https://www.jota.info/paywall?redirect_to=// www.jota.info/opiniao-e-analise/artigos/as-tres-correntes-do-direito-ao-esquecimento18062017. Acesso em: 09 jul. 2019.

TEPEDINO, Gustavo. Normas Constitucionais e Direito Civil. Revista da Faculdade de Direito de Campos, ano IV, n. 4, ano V, n. 5, 2003-2004. Disponível em: http://www.uniflu.edu.br/arquivos/Revistas/Revista04e05/Docente/10.pdf. Acesso em: 09 jul. 2019.

UE. Parlamento Europeu. Directiva 95/46/CE do Parlamento Europeu e do Conselho, de 24 de outubro de 1995. Disponível em: https://eur-lex.europa.eu/legalcontent/PT/TXT/PDF/?uri=CELEX:31995L0046\&from=EN. Acesso em: 09 jul. 2019.

UE. Parlamento Europeu. Regulamento (UE) 2016/679 do Parlamento Europeu e do Conselho, de 27 de abril de 2016. Relativo a proteção das pessoas singulares no que diz respeito ao tratamento de dados pessoais e a livre circulação desses dados e que revoga a Diretiva 95/46/CE 
(Regulamento Geral sobre a proteção de dados). Disponível em: https://eur-lex.europa.eu/legalcontent/PT/TXT/?uri=CELEX\%3A32016R0679. Acesso em: 09 jul. 2019.

VOSS, W. Gregory; CASTETS-RENARD, Céline Casters. Proposal for na international taxonomy on the various forms of the "Right to be Forgotten": a study on the convergence of norms. Colo Tech L. J., v. 14, n. 2, 23 maio 2016. Disponível em: https://ctlj.colorado.edu/wp-

content/uploads/2016/06/v.3-final-Voss-and-Renard-5.24.16.pdf. Acesso em: 09 jul. 2019. 